\title{
Rheumatic heart failure: A review of clinical status and meta-analysis of echocardiography diagnosis and efficacy of shorter duration of antibiotic
}

\author{
Aref Albakri* \\ St-Marien Hospital Bonn Venusberg, Department of Internal Medicine, Bonn, Germany
}

\begin{abstract}
Rheumatic heart failure (RHF) is a potentially preventable cardiac complication of rheumatic fever (RF) characterized by scarring or stretching in one or more cardiac valves leading to low cardiac output. Over the past five decades, the epidemiology of RHF has shifted markedly, reducing in high-income countries while increasing in low/middle-income countries. However, the shift has lacked a matching proportional expansion in research and public health practices. Prophylactic and curative therapies combined with targeted public health control programs have been associated with the reducing prevalence in high-income countries but such strategies either have not been adequately implemented or have not translated into reduced burden in low-income countries. Further, the lack of recent research has undermined access to evidence-based data to support the development of treatment guidelines appropriate for low/middle-income countries. In the present paper, we review published data to provide a comprehensive update on epidemiology, pathophysiology, diagnosis, and management strategies for RHF.
\end{abstract}

\section{Introduction}

Rheumatic fever (RF) is an acute complication of the bacterium, Group of A streptococcal (GAS) infection, whose recurrent episodes may lead to the development of rheumatic heart disease (RHD) and its life-threatening sequalae, rheumatic heart failure (RHF) [1,2]. Over the past five decades, the incidence of RF has declined considerably in high-income countries but remains endemic in low- and middleincome countries as well as in marginalized populations in highincome countries [3]. Conversely, the declining incidence in highincome countries combined with an emphasis on other preventable endemic diseases such as malaria and HIV/AIDS have influenced a parallel reduction in research into RF [4]. Although more than a century of data from North America and Europe greatly improved clinical management of RF/RHF, the shift in RF incidence may warrant gathering recent data from low- and middle-income countries [2] in which RHF is a major cause of morbidity and premature deaths as well as imposes a substantial burden on their healthcare systems $[5,6]$. Recent data would also be useful for designing appropriate evidencebased guidelines for primary and secondary prophylactic strategies. In particular, secondary prevention strategies that rely on accurate case detection for appropriate indication for prophylactic antibiotics and for medical surveillance. Additionally, obtaining exact epidemiology data on the prevalence and incidence is highly desirable to facilitate healthcare planning $[2,7]$. Thus, the present review synthesizes data from published clinical trials and expert consensus, as well as conducts two meta-analyses on RHF diagnosis and management intended to produce a comprehensive understanding of the clinical status of RHF.

\section{Definition}

$\mathrm{RF}$ is a delayed sequalae to untreated pharyngeal infection by GAS mostly affecting susceptible children in the age bracket of five to fifteen years for the first time but its cardiac effects often first present many years later in adulthood [2,5]. In some individuals, GAS infection may lead to an autoimmune consequence causing widespread inflammatory response and illness selectively affecting the heart, joints, brain and skin. While the effect is transient on the brain, joints and skins, it is persistent on the heart valves [6]. Individual with previous RF episodes are much more likely to experience recurrent episodes producing additive injuries to cardiac valves leading to progressive and permanent valvular lesion clinically termed RHD and its sequalae, RHF [6,7]. A majority of studies define RHF as persistent inflammation of the heart after acute or recurrent RF episodes causing stretching and/or scarring of the mitral and/or aortic cardiac valves with a consequent reduction in coronary perfusion or leakage of the valves causing blood to flow in the reverse direction. The effect on cardiac valves may eventually lead to arrhythmias such as atrial fibrillation (AF) and the inability of the heart to pump amount of blood commensurate with the body's metabolic needs $[2,7]$.

\section{Epidemiology}

Precise epidemiological data on RHF is conspicuously lacking. Although the WHO in conjunction with the Global Burden of Disease (GBD) study have collected extensive regional and global data on the prevalence, mortality and disability of major world diseases, they have focused on RHD with RHF only mentioned as a cause of death in RHD patients. While some authors may have used RHD interchangeably

${ }^{\star}$ Correspondence to: Aref Albakri, St-Marien hospital Bonn Venusberg, Department of Internal Medicine, Bonn, Germany, E-mail: arefalbakri@yahoo.com

Key words: rheumatic heart disease, rheumatic heart failure, rheumatic valvular disease, rheumatic fever

Received: December 01, 2018; Accepted: December 14, 2018; Published: December 22, 2018 
with RHF regarding mortality, the two are different clinical entities with $\sim 27 \%$ of RHD patients developing RHF within five years [8]. Because of the lack of specific data on RHF, this review paper relies on available published data on RHD to get an insight into the prevalence and trends of RHF. The latest epidemiological data published by the GBD Study in 2016 estimates RHD affects 30 million individuals worldwide [9]. In 2015, RHD was responsible for an estimated 305,000 deaths and 11.5 million disability-adjusted life years lost. Of these deaths, $60 \%$ were premature (in individuals aged $\leq 70$ years) [10]. Even with significant improvement and widespread utility of efficacious prophylactic and therapeutic measures as well as targeted public health activities, the proportion of RHD to overall global mortality between the years 2000 and 2015 remains relatively the same [11].

The prevalence of RHD varies significantly across world regions attributed to disparities in income levels of individual countries. It is endemic in low- and middle-income countries. It is more prevalent in the African, South-East Asia and Western Pacific regions, accounting for $84 \%$ of all prevalent cases and $80 \%$ of all estimated RHD-associated deaths in 2015 [9]. India and South-East Asia have the highest global prevalence, accounting for $27 \%$ of all cases worldwide. In the Western Pacific Region, the greatest burden is in China and in the indigenous population in Australia, New Zealand and Pacific Island States. In the Eastern Mediterranean Region, it is endemic in Egypt, Sudan and Yemen [10]. The disparities in RHD prevalence in low- and high-income countries has been associated to socio-economic and environmental factors such as poor housing, undernutrition, overcrowding and poverty, which are well-demonstrated contributors to the incidence, magnitude and severity of RHD [10,11].

The prevalence of RHD also exhibits a gender-specific bias, disproportionately affecting girls and women. Females have a two-fold increase in the risk of RHD compared to males and account for twothirds of RHD-associated hospitalization in Africa, India and Yemen [9]. In regions where RF is endemic, RHF is the principle cardiac condition in pregnancy women associated with significant maternal and perinatal morbidity and mortality [10]. Finally, age also has a significant influence in the prevalence of acute RF (ARF) and RHD. Although uncommon in pediatric population in the age-bracket 5-14 years, the highest prevalence in this cohort is in sub-Saharan Africa (affecting five per 1000); the Pacific and Indigenous population of Australia and New Zealand (3.5 per 1000) and South Central Asia (2.2 per 1000) and lowest in high-income countries (0.5 per 1000) [12]. While ARF peaks in childhood, the prevalence of RHD increases with age, peaking in young adults aged 25 to 34 years, suggesting the culmination of ARF episodes in the previous decades [13-15].

\section{Risk factors}

Several decades of research has firmly established RF as the cardinal cause of RHF [2]. However, not all cases of RF progress into RHF. This observation raised the possibility of the existence of a subgroup of patients with characteristics that prevent the progression of RF to
RHF [5]. The most conspicuous evidence of risk factors of RHF is the epidemiologic shift in RHF burden, reducing in high-income countries while increasing in low-income countries [8-10]. In 2004, WHO [10] implicated socio-economic and environmental, and health-related factors as major determinants of the magnitude and severity of RHF (Table 1) [10].

\section{Socio-economic}

The 2016 GBD study [9], and WHO report in RF and RHD [10] associate socio-economic and environmental factors to the increasing RHF burden in low- and middle-income countries. Factors such as poverty, undernutrition and overcrowding are common characteristics in high-burden RHF marginalized communities and countries [11,1619]. In a Bangladeshi case-controlled study of $206 \mathrm{RF} / \mathrm{RHD}$ patients with 207 age-matched controls, the risk of RHD was higher among patients living in overcrowded environment (Odds Ratio: OR, 2.4, 95\% CI 1.24.7) and having low-literacy levels (OR, 2.4, 95\% CI 1.1-5.2). Individuals with low education level, in labor-intensive occupation, living in urban centers and in brick houses a trend towards increased likelihood of RHD [16]. Another Bangladesh hospital-based case-controlled study of $44 \mathrm{RF}$ pediatric patients associated low-income $(\mathrm{OR}, 2.37 ; \mathrm{p}=0.04)$, poor living condition/substandard kacha house (OR, 2.93, $\mathrm{p}=0.02)$, poor nutritional status (OR, 2.68; $\mathrm{p}=0.04)$ with increased likelihood for RHF [17]. A Ugandan study of 203 RHD patients with age and sexmatched controls associated increased risk of RHF with unemployment (OR, 1.7, 95\% CI: 1.05-8.19) and overcrowding (OR, 1.35, 95\% CI: 1.11.56) [18]. In Fiji, a case controlled study of 80 cases of RHD reported poor-quality housing and lower socio-economic status, maternal employment increased RHF risk [19]. Socio-economic factors increase the risk of RHF by providing conducive conditions for rapid spread of infection and increasing rates or recurrent of infection and incidence RHD [10].

\section{Health-related}

Health-related factors is another significant risk factors associated with a high RGF burden in low and middle-income countries. In a 2004 WHO report, factors such as shortage of healthcare resources, inadequate expertise of healthcare providers and low-level awareness of $\mathrm{RF} / \mathrm{RHD} / \mathrm{RHF}$ in the community increase the incidence of RHF. These factors lead to more severe evolution of the disease, high recurrent rates, severe RHD and increased healthcare costs in relation with repeat hospitalization or expensive surgical intervention. In addition, these factors also contribute towards inadequacy of diagnosis and treatment of GAS infection, misdiagnosis or delayed diagnosis of RHF and inadequacy or non-compliance with secondary prophylaxis [10]. Besides internal health-related factors, healthcare accessibility is another major factor, which affects individuals living in lowincome countries. Distance from healthcare facility ( $>5$ kilometers) has been associated with reduced access to healthcare and uptake of interventional programs in low-income countries [20,21]. In particular, in Uganda, interaction between overcrowding and long distances to

Table 1. Risk factors of rheumatic heart failure [10]

\begin{tabular}{|c|c|c|c|}
\hline Risk Factors & Examples & Effect & Impact on RHF \\
\hline Socioeconomic \& environmental factors & $\begin{array}{l}\text { Poverty; undernutrition; overcrowding; or } \\
\text { poor housing }\end{array}$ & $\begin{array}{l}\text { Rapid spread of GAS infection } \\
\text { Difficulties in accessing care }\end{array}$ & $\begin{array}{l}\text { Increased incidence of ARF } \\
\text { Higher rates of recurrent ARF }\end{array}$ \\
\hline Healthcare-related factors & $\begin{array}{l}\text { Shortage of healthcare resources; inadequate } \\
\text { expertise of healthcare providers; or low- } \\
\text { level awareness of diseases in the community }\end{array}$ & $\begin{array}{l}\text { Inadequate diagnosis and treatment of GAS } \\
\text { infection. } \\
\text { Misdiagnosis or delayed diagnosis of ARF. } \\
\text { Inadequate or non-compliance with } \\
\text { secondary prophylaxis. }\end{array}$ & $\begin{array}{l}\text { Higher incidence of ARF and its recurrence } \\
\text { Patient unawareness of the disease } \\
\text { More severe evolution of the disease } \\
\text { Higher recurrent rates and severe RHD } \\
\text { High healthcare costs- repeat hospitalization } \\
\text { and surgical interventions }\end{array}$ \\
\hline
\end{tabular}


healthcare facility (OR, 1.20, 95\% CI: 1.05-1.42) has been associated with an elevated risk of developing RHF [18].

\section{Pathogenesis}

Kaplan et al. made the initial demonstration of antibodies against GAS reacting with human heart preparations in 1964 [22,23]. Since then, it has been well understood that pathogenesis of RHF in a susceptible host (individual) involves a GAS infection and exacerbated autoimmune response [3,5] (Figure 1).

\section{Susceptible host}

Untreated GAS infection has been identified as the cause of RF. However, only $0.3-3 \%$ of individuals with acute streptococcal pharyngitis develop RF $[7,24]$. In these susceptible hosts, humoral and cellular autoimmune response to streptococcal antigens is believed to mediate the development of RF [7]. Pedigree studies suggest a genetically controlled autoimmune response where high-responsiveness to streptococcal cell-wall antigen is expressed through a single recessive gene while low-responsiveness is expressed through a single dominant gene. The gene controlling low-level response to streptococcal antigen has been linked to Class II human leukocyte antigen (HLA) [7] or to a susceptibility gene present at or nearby the HLA-DR locus $[25,26]$.

Molecular typing techniques allowed the identification of the association between RF and class II HLA alleles but particular alleles responsible for susceptibility or protection vary between populations [27-29]. Specific B-cell alloantigen have also been associated with susceptibility to RF. Mouse monoclonal antibodies prepared against B-cells from RHD patients showed D8/17 reacted with higher numbers of B-cells compare to ARF/RHD controls. The expression of D8/17 was also in a high proportion of B-cells in patients with current or previous ARF and in moderate proportion of B-cells in first-degree family members suggesting inherited susceptibility [30]. A strong association between D8/17 expression and ARF has been found in several populations - North America, the Caribbean, Israel, Russia, Mexico and Chile [30-34]. Although exceptions have been observed in

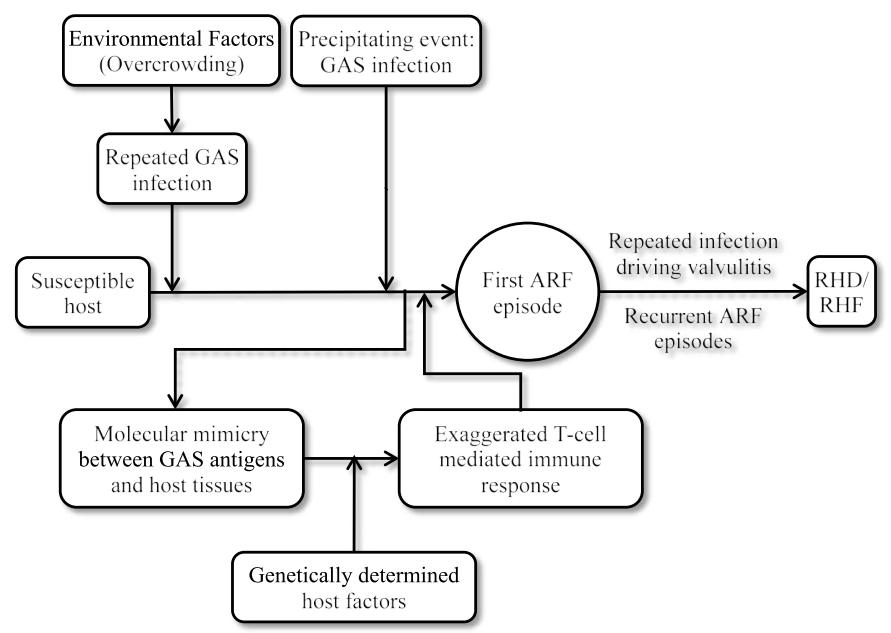

Figure 1. Pathogenesis of rheumatic heart failure

Pathogenesis of RHF results from the triad of a genetically susceptible host, initial or recurrent GAS infection and exacerbated autoimmune response. Development of ARF from GAS infection occurs through molecular mimicry between GAS antigens and host cardiac myosin tissues, and exaggerated T-call mediated autoimmune response. Repeated ARF episodes produce additive insult to cardiac valves causing them to scarring and stretching. Continued insult eventually leads to the development of RHF. Reproduced from Carapetis et al., 2005, p. 157 [3] the U.S. and India [35,36], B-cell alloantigen markers can be used for identifying individuals with or at risk of ARF or RHF [41].

\section{GAS infection}

Epidemiological data and laboratory evidence from the first half of the 20th Century established that only pharyngeal infection by GAS is the sole etiologic agent of ARF [37,38]. In the next half, the clinical relevance of variations in the virulence strains of GAS has become clearer. Skin infection by GAS and documented outbreaks of impetigo caused by glomerulonephritis do not lead to ARF [39]. The role of GAS infection in ARF is complex but recurrent infection is necessary to prime autoimmune response before the initial ARF episode occurs [40]. It has been also hypothesized that in tropical countries with a high prevalence of pyoderma and RHD, skin infections by GAS may have a priming role or even cause ARF directly or subsequent pharyngeal infection. Group C or G streptococci may play a pathogenic role since they are more commonly isolated than GAS from the throat in tropical countries and can acquire virulent factors by horizontal transmission from GAS [3].

\section{Immune response}

Exacerbated autoimmune response is the hallmark of pathogenic mechanism for RHF. It is a consequence of molecular mimicry between epitopes on GAS (pathogen) and specific human tissues [3,5]. GAS cell wall consists of carbohydrates such as $\mathrm{N}$-acetyl beta $\mathrm{D}$-glucosamine. GAS also contain $\mathrm{M}, \mathrm{T}$ and $\mathrm{R}$ surface proteins and lipoteichoic acid, which are involved in bacterial adherence to throat epithelial cells. The M protein is the most important GAS antigen sharing structural homology with alpha-helical coiled human proteins such as cardiac myosin, tropomyosin, keratin, laminin, vimentin and several valvular proteins [40]. Thus, structural and immunological similarities between GAS M protein and myosin alpha-helical and coiled-coil molecules are essential to the development of rheumatic carditis and valvulitis [41]. During an ARF episode, there is increased production of inflammatory acute phase proteins such as Mannan-binding lectin (MBL), and cytokines IL-1, IK-6 and TNF-alpha to eliminate GAS. In RHF patients, production of these proteins is genetically controlled and mutation can lead to differential expression and secretion to cause damage. MBL binds to $\mathrm{N}$-acetyl beta $\mathrm{D}$-glucosamine on the GAS cell wall to activate the complement-lectin pathway inducing elimination of the bacteria. Mutations in the gene coding for MBL production in RHF patients may interfere with the elimination of GAS [42].

Molecular mimicry mediated by genetically host-determined factors may trigger an exaggerated $\mathrm{T}$-cell mediated immune response. $\mathrm{CD}^{+} \mathrm{T}$ cells are major effectors of autoimmune response in cardiac tissues of RHF patients [43-45]. Presentation of GAS antigens via class II HLA molecules triggers the activation of $\mathrm{CD} 4^{+} \mathrm{T}$ cells. GAS epitopes presenting structural or sequential homology with host epitopes can activate auto-reactive T-lymphocytes that escaped immune tolerance by molecular mimicry mechanism. The auto-reactive T-cells can also activate B-cells producing pathogen and host-antigen specific antibodies [41]. Recent evidence demonstrate humoral and cellular immune reactions in RHF patients. In rheumatic carditis, streptococcal and human protein cross-reactive antibodies, there is upregulation of the adhesive molecule VCAM-1 after binding to the endothelial surface resulting into inflammation, cellular infiltration and valvular scarring $[46,47]$. These findings establish the role of cardiac tissue cross-reactive antibodies (anti-cardiac myosin and laminin) in the early stages of inflammation and T-cell infiltration in RHF lesion [41]. 
Valvulitis rather than rheumatic carditis is responsible for RHF morbidity and mortality [48-50]. Since myosin is absent in in cardiac valves, autoimmune response against myosin induces valvulitis via the presence of laminin, another alpha-helical coiled-coil molecule found in the valvular basement membrane and around the endothelium recognized by T-cells against myosin and M protein [46]. Antibodies to cardiac valve tissues have also been observed to cross-react with $\mathrm{N}$-acetyl glucosamine in group A carbohydrate [51]. Exaggerated antibody response to group A carbohydrate has been observed in ARF patients, which remained elevated in individuals with residual mitral valve disease supporting the suggestion that these antibodies cause valvular damage $[52,53]$. It is not clear whether the initial valvular injury results from antibody or cell mediated autoimmune damage but T-cell and macrophage infiltration are involved in subsequent damages $[54,55]$.

\section{Clinical features and diagnosis}

RHF remains a clinical diagnosis mostly based on Jones criteria and laboratory tests to support diagnosis, and echocardiographic tests to diagnose cardiac involvement $[7,10]$.

\section{Jones criteria for RHF diagnosis}

Introduced in 1944, the Jones criteria for diagnosis of RF and carditis were divided into major and minor categories based on the prevalence and specificity of clinical features. Major criteria comprising of carditis, joint symptoms, subcutaneous nodules, chorea and a history of RF or pre-existing RHD indicate a high likelihood of positive diagnosis. On the other hand, minor criteria comprising of clinical findings (fever and erythema marginatum, abdominal pain, epistaxis and pulmonary findings), and laboratory markers of acute inflammation (leukocytosis, and elevated erythrocyte sedimentation rate or C-reactive protein are suggestive but insufficient for a positive diagnosis $[13,56]$. The Jones criteria proposed the presence of two major criteria or one major and two minor criteria was reasonable clinical evidence of rheumatic activity [56]. Since its introduction, the American Heart Association (AHA) [57] and the New Zealand RHF association have revised the Jones Criteria. In a recent revision in 2015, the AHA aimed to improve specificity and address vexing clinical issues for all patient population with evidence of preceding pharyngeal GAS infection [57]. The revised criteria proposed diagnosis of initial ARF should be based on the presence of 2 major, or 1 major and 2 minor criteria; and diagnosis of recurrent ARF should be based on 2 major, or 1 major and 2 minor, or 3 minor criteria (Table 2).

Major criteria: Carditis or valvulitis is the most consistent cardiac pathology of RF leading to permanent valvular damage. Its diagnosis is based on auscultation of typical cardiac murmurs indicating mitral and/or aortic valve regurgitation [57]. About 50 to $65 \%$ of individuals with RF have clinically detectable carditis with occasional pericarditis and myocarditis. Severe carditis occurs in about $20 \%$ and can lead to RHF. Mild rheumatic carditis is subclinical in approximately $30 \%$ detectable by echocardiography but inaudible by auscultation [58]. Rheumatic carditis can evolve over weeks or months underscoring the importance of repeat echocardiography in 2 to 4 weeks if the initial echocardiography has normal findings [57].

Arthritis: Arthritis is the most frequent major extra-cardiac manifestation of RF found in up to $75 \%$ of patients with an initial episode of RF. It occurs early in the course of the disease usually as the presenting complaint. Involvement of joints in RF may range from arthralgia to disabling arthritis but without objective findings do not qualify as major disease manifestation because of non-specificity [7]. Particularly, arthritis manifestation of RF occur as migratory polyarthritis mostly in the larger joints causing pain, swelling, movement limitation and local heat. Joint manifestation is not easy to assess in clinical practice because good response to non-steroidal anti-inflammatory drugs (NSAIDs), which mask the symptoms. Monoarthritis especially involving the hips also a presenting feature in population with a high incidence of RF $[58,59]$.

Chorea: Chorea affect up to $15 \%$ of individuals with RF and is more prevalent in females and adolescents [60]. It consists of involuntary jerky movements that may be asymmetrical, facial, grimacing fidgeting and emotional liability. It may manifest as deterioration in handwriting, inability to feed and unsteady gaits with falls. Often, it occurs after a long latent period (up to six months) post streptococcal infection and usually after resolution of other inflammatory features of RF. Chorea may follow a fluctuating course over many months or even years before resolving. Up to $60 \%$ of individuals with chorea will have residual RHF [61] and up to $20 \%$ may have long-term neuro-psychiatric problems $[62,63]$.

Subcutaneous nodules: Subcutaneous nodules are tiny $(<2 \mathrm{~cm}$ in diameter) firm, painless mobile nodules occurring over bony prominences or extensor tendons. Common locations are elbows, wrists, knees and ankles. They may occasionally occur as Achilles tendon and spine. There are a rare manifestation of RHF occurring in about $>5 \%$ of cases $[64,65]$. They may last up to two weeks during the inflammatory phase and occur in association with carditis [57,59].

Erythema marginatum: They are a rare manifestation of RHF occurring in $<5 \%$ of reported cases. It is an annular erythema found on the torso, upper arms and legs. Macules and papules usually spread outwards with raise edges [59]. They are not itchy or painful and fluctuate over many weeks. It is difficult to identify in individuals with darker skin [57].

Minor criteria: Arthralgia is a minor criteria because it lacks diagnostic specificity. In the presence of polyarthritis, arthralgia cannot

Table 2. The 2015 AHA revised jones criteria [57]

\begin{tabular}{|c|c|c|}
\hline Criteria & Type & Clinical Manifestations \\
\hline \multirow{2}{*}{$\begin{array}{l}\text { All patient population with prior } \\
\text { GAS infection }\end{array}$} & Initial ARF & 2 major or 1 major +2 minor manifestation \\
\hline & Recurrent ARF & 2 major or 1 major +2 minor, or 3 minor manifestations \\
\hline \multirow[b]{2}{*}{ Major criteria } & Low-risk population & Carditis (clinical/subclinical); arthritis (polyarthritis only); chorea; erythema marginatum; subcutaneous nodules \\
\hline & Moderate/high risk population & $\begin{array}{l}\text { Carditis (clinical/subclinical); arthritis (monoarthritis/polyarthritis, polyathralgis); chorea; erythema marginatum; } \\
\text { subcutaneous nodules }\end{array}$ \\
\hline \multirow{2}{*}{ Minor Criteria } & Low-risk population & $\begin{array}{l}\text { Polyarthralgia; fever }\left(\geq 38.5^{\circ} \mathrm{C}\right) ; \mathrm{ESR} \geq 60 \mathrm{~mm} \text { in the first hour and/or CRP } \geq 3.0 \mathrm{mg} / \mathrm{dL} \text { : prolonged PR interval, } \\
\text { after accounting for age variability (unless carditis is a major criterion) }\end{array}$ \\
\hline & Moderate/high risk population & $\begin{array}{l}\text { Monoarthralgia; fever }\left(\geq 38.5^{\circ} \mathrm{C}\right) ; \mathrm{ESR} \geq 30 \mathrm{~mm} / \mathrm{h} \text { and/or } \mathrm{CRP} \geq 3.0 \mathrm{mg} / \mathrm{dL} ; \text { Prolonged PR interval, after } \\
\text { accounting for age variability (unless carditis is a major criterion) }\end{array}$ \\
\hline
\end{tabular}

ARF: Acute rheumatic fever; CRP: C - reactive protein; ESR: Erythrocyte Sedimentation Rate; GAS: Group A Streptococcal; Low-risk population: ARF incidence $\leq 2$ per 100,000 school-age children or all-age rheumatic heart disease prevalence of $\leq 1$ per 1,000 per year 
be used as a minor criteria. When NSAIDs have been used, there may be observable clinical signs of arthritis. Joint manifestations take a fluctuating course (from mild to incapacitating) over days up to several weeks and it is challenging to distinguish arthritis from arthralgia using patient clinical history alone [59].

Fever: Fever in RHF patients occurs with varying patterns. It is sensitive to anti-inflammatory medication. The use of paracetamol and NSAIDs reduce the period of fever. However, high fever may persist in RF patients with exacerbated inflammatory response with evolving arthritis and carditis [7]. In high-risk populations, fever greater than $38^{\circ} \mathrm{C}$ is considered sufficient evidence and minor criterion for RHF $[57,58]$.

Elevated acute phase reactants: Individuals with RF exhibit elevated erythrocyte sedimentation rate (ESR) $>50 \mathrm{~mm}$ in the first hour. ESR remains elevated for several weeks ever after resolution of symptoms, and can take several months to return to normal levels. ESR is nonspecific because they occur in other forms of bacterial infection and inflammatory conditions [59].

First degree heart block: First degree heart block is considered a minor criteria in the absence of carditis, which supports the diagnosis of RHF. Results of electrocardiographic PR interval should be interpreted based on the age and heart rate of the patient. In pediatric populations, the upper limit of a normal PR interval is 0.16 seconds ( $<12$ years) and 0.18 seconds ( $=12$ years) [57-59].

Laboratory test for evidence of GAS infection: Laboratory tests are included within the Jones criteria. A positive pharyngeal culture or elevated streptococcal antibody titer usually confirms immune response to GAS pharyngitis [58]. During acute onset of RHF, there is elevated ESR, fibrinogen and C-reactive protein (CRP), which may occur over several weeks after clinical signs of ARF has disappeared and decline over several months [66]. Since other disease may resemble HRF, laboratory evidence of prior GAS infection is required. Evidence of prior infection include the following findings: (a) a fourfold rise or fall in streptococcal antibodies titer; (b) positive throat culture for GAS; and a positive rapid GAS carbohydrate antigen test in a child with a high pretest probability of GAS pharyngitis [57]. ECG may be used to clarify the nature of heart rhythm and conduction disorders [66].

\section{Echocardiography}

Echocardiography is useful in detecting cardiac involvement in RHF patients. It provides cardiac morphological and functional information about atrial and ventricular sizes, valvular thickening, leaflet prolapse, coaptation failure, restricted leaflet motility and ventricular dysfunction. It is also useful for diagnosis of mitral and/or valve insufficiency and exclusion of non-rheumatic etiologies such as congenital mitral valve cleft and/or anomalies, degenerative floppy mitral valve and acquired valvular diseases $[67,68]$. In 2012, the World Health Federation (WHF) developed new echocardiographic guidelines for the full spectrum of rheumatic diseases based on best available evidence [69]. The guidelines define three categories based on assessment by $2 \mathrm{D}$, continuous wave and color-Doppler echocardiography: (a) definite RHF; borderline RHF and normal RHF (Table 3). The criteria also provides criteria for pathological mitral and aortic regurgitation (Table 4) and morphological features of RHF (Table 5).

The 2015 scientific statement from AHA recommends echocardiography with Doppler should be performed (a) in all cases of confirmed and suspected RHF; (b) in any patients diagnosed or suspected with RHF even in the absence of carditis on diagnosis; (c) to assess for the presence of carditis in the absence of auscultatory findings, especially in moderate to high risk populations and when RHD is considered likely [57]. Other useful imaging tests include chest radiography to assess cardiac size, pericarditis, pulmonary edema and increased vascularity; radionuclide imaging to identify rheumatic carditis by non-invasive means but with insufficient evidence to support clinical use; and endomyocardial biopsy to detect Aschoff nodules [59].

\section{Differential diagnosis}

The 2015 AHA statement on diagnosis of RHF underscores the value of a working differential diagnosis when evaluating each of the major criteria for RHF diagnosis. Echocardiography-based criteria for diagnosing carditis (Tables 4 and 5) in the absence of clinical evidence requires knowledge of other etiologies resembling rheumatic carditis. Table 6 provides a list of alternative diagnosis to consider when assessing carditis, arthritis and chorea.

\section{Meta-analysis of RHF diagnosis}

Diagnosis of RHF is challenging due to the lack of a gold standard test, which would also be useful as a reference test as well

Table 3. Echocardiographic criteria for diagnosis of RHF [69]

\begin{tabular}{|c|c|}
\hline \multicolumn{2}{|c|}{ Echocardiographic Criteria for Individuals $\leq 20$ years } \\
\hline \multirow{4}{*}{ Definite RHF (A, B, C or D) } & A. Pathological MR $+\geq 2$ morphological features of RHF of the MV \\
\hline & B. MS mean gradients $\geq 4 \mathrm{~mm} \mathrm{Hg}$ \\
\hline & C. Pathological $\mathrm{AR}+\geq 2$ morphological features of RHF of the AR \\
\hline & D. Borderline disease of both $\mathrm{AV}$ and $\mathrm{MV}$ \\
\hline \multirow{3}{*}{ Borderline RHF (A, B, or C) } & A. $\geq 2$ morphological features of RHF of the MV in the absence of pathological MR/MS \\
\hline & B. Pathological MR \\
\hline & C. Pathological AR \\
\hline \multirow{4}{*}{ Normal Findings (All A to D) } & A. MR does not meet all 4 Doppler echocardiography criteria \\
\hline & B. AR does not meet all 4 Doppler echocardiography criteria \\
\hline & C. Isolated morphological features of RHF of the MV in the absence of associated pathological stenosis or regurgitation \\
\hline & D. Morphological features of the RHF of the $\mathrm{AV}$ int eh absence of associated pathological stenosis or regurgitation \\
\hline \multicolumn{2}{|c|}{ Echocardiographic Criteria for Individuals $>20$ years } \\
\hline \multirow{4}{*}{ Definite RHF (A, B, C, or D) } & A. Pathological MR $+\geq 2$ morphological features of RHD of the MV \\
\hline & B. MS mean gradient $\geq \mathrm{mm} \mathrm{Hg}$ \\
\hline & C. Pathological $\mathrm{AR}+\geq 2$ morphological features of the $\mathrm{AV}$ (only in individuals $<35$ years) \\
\hline & D. Pathological $\mathrm{AR}+\geq 2$ morphological features of RHD of the MV \\
\hline
\end{tabular}

AR: Aortic Regurgitation; AV: Aortic Valve; MR: Mitral Regurgitation; MS: Mitral Stenosis; MV: Mitral Valve; RHD: Rheumatic Heart Disease; WHF: World Heart Federation 
Table 4. Doppler criteria for pathological regurgitation (rheumatic carditis) [69]

\begin{tabular}{|l|l|}
\hline \multirow{3}{*}{ Pathological MR (meet all A to D) } & A. Seen in two views \\
\hline B. $\geq 1$ view, jet length $\geq 2 \mathrm{~cm}$ \\
\hline C. Velocity $\geq 3 \mathrm{~m} / \mathrm{s}$ for one complete envelope \\
\hline Pathological AR (meet all A to D) & D. Pan-systolic jet in at least one envelope \\
\hline & B. $\geq 1$ veen in 2 views \\
\hline & C. . Velocity length $\geq 2 \mathrm{~cm}$ \\
\hline D. Pan-diastolic jet in at least one envelope \\
\hline
\end{tabular}

Table 5. Criteria for morphological features of rheumatic carditis [69]

\begin{tabular}{|l|l|}
\hline \multirow{5}{*}{ Features in the MV } & A. AMVL thickening $\geq 3 \mathrm{~mm}$ (age-specific) \\
\hline B. Chordal thickening \\
\hline Features in the AV & C. Restricted leaflet motion \\
\hline D. Excessive leaflet tip motion during systole \\
\hline A. Irregular or focal thickening \\
\hline B. Coaptation defect \\
\hline C. Restricted leaflet motion \\
\hline D. Prolapse \\
\hline
\end{tabular}

AMVL: Anterior Mitral Valve Leaflet; AV: aortic valve; MS: Mitral Stenosis; MV: Mitral Valve

Table 6. Differential diagnosis of carditis, arthritis and chorea [57]

\begin{tabular}{|c|c|c|}
\hline Carditis & Arthritis & Chorea \\
\hline $\begin{array}{l}\text { Septic arthritis; Connective } \\
\text { tissue and other autoimmune } \\
\text { diseases; Viral arthropathy; } \\
\text { Reactive arthropathy; Lyme } \\
\text { disease; Sickle cell anemia; } \\
\text { Infective endocarditis; } \\
\text { Leukemia or lymphoma; } \\
\text { Gout and pseudo gout; } \\
\text { Post-streptococcal reactive } \\
\text { arthritis; Henoch-Schonlein } \\
\text { purpura }\end{array}$ & $\begin{array}{l}\text { Physiological mitral } \\
\text { regurgitation; Mitral valve } \\
\text { prolapse; Myxomatous } \\
\text { mitral valve; Fibroelastoma } \\
\text { Congenital mitral valve } \\
\text { disease; Congenital } \\
\text { aortic valve disease; } \\
\text { Infective endocarditis; } \\
\text { Cardiomyopathy } \\
\text { Myocarditis; viral or } \\
\text { idiopathic Kawasaki disease }\end{array}$ & $\begin{array}{l}\text { Drug intoxication; Wilson } \\
\text { disease; Tic disorder } \\
\text { Choreoathetoid cerebral } \\
\text { palsy; Encephalitis; } \\
\text { Familial chorea; Intracranial } \\
\text { tumor; Lyme disease; } \\
\text { Hormonal; Metabolic; } \\
\text { Antiphospholipid antibody } \\
\text { syndrome; Autoimmune: } \\
\text { Systemic lupus } \\
\text { erythematosus, systemic; } \\
\text { Vasculitis; Sarcoidosis; } \\
\text { Hyperthyroidism }\end{array}$ \\
\hline
\end{tabular}

as for developing supportive clinical tests. Current recommended diagnostic guidelines rely on the presence or the absence of major and/ or minor clinical features (the Jones criteria) usually supported with echocardiographic evidence of cardiac involvement $[57,69]$. While the Jones criteria has been modified over time by different organizations to improve its diagnostic accuracy, concerns persist that even with the revisions there are several documented cases of under- or overdiagnoses. In particular, the Jones criteria does not detect subclinical or "silent" carditis because it is missed by cardiac auscultation [57] Consequently, to improve the diagnosis of carditis in patients suspected with RF, WHO developed echocardiographic criteria based on 2D and color-Doppler echocardiography [69]. Already, there are suggestions that Doppler echocardiography allows the detection of valvular incompetence in the absence of heart murmurs on auscultation. In the present meta-analysis, we sought to determine whether Doppler echocardiography detects subclinical carditis in the acute or quiescent stages of the disease missed by clinical evaluation.

Search strategy and eligibility criteria: We searched PubMed/ MEDLINE, EMBASE, African Journals Online and Google Scholar for studies on clinical and echocardiographic diagnosis of RHF published between 1990 and 2018 without any language restriction. The search was restricted to the past 30 years as a representative of the present prevalence rates of RHF. The key search terms used were: "rheumatic fever" OR "rheumatic heart" OR "streptococcal pharyngitis" AND "Jones Criteria" OR "echocardiography". Additional studies were identified from screening of bibliographies of the included studies as well as related review articles. The eligibility criteria were as follows: the study (a) included patients suspected with RF/RHF; (b) used modified Jones and/or echocardiographic criteria for diagnosis; (c) reported diagnostic outcomes including cases of detected subclinical carditis, and mitral and/or aortic valve incompetence. Two authors independently screened all titles and abstracts, reviewed full-text articles and assessed their eligibility for inclusion. Disagreements between the two reviewers were resolved by discussion and a final decision reached after mutual agreement.

Data abstraction and analysis: From each included study, two reviewers independently recorded salient study characteristics: first author, year of publication, country of study, demographic details of participants, criteria used for diagnosis of mitral/aortic regurgitation and cases of positive diagnosis. We differentiated between clinical carditis (defined as the presence of heart murmurs on cardiac auscultation that is consistent with echocardiographic evidence of valvular regurgitation, and subclinical or silent carditis defined as pathological regurgitation or mitral stenosis or morphological changes in the absence of heart murmur on auscultation (Table 7). We used Comprehensive MetaAnalysis software version 2 to analyze the extracted data. Summary estimates were calculated for all studies as well as weighted outcomes, their $95 \%$ clearance intervals. To account for heterogeneity due to screening method (Jones criteria or echocardiography), we estimated $\mathrm{I}^{2}$ summary statistics distinguished between low (25\%), moderate $(50 \%)$ and high (75\%). Findings were statistically significant when $\mathrm{p}<0.01$.

Study characteristics and outcomes: The online search yielded 641 articles for consideration. Titles and abstracts were reviewed and together with studies identified by the manual bibliography search, 32 studies were potentially eligible and selected for possible inclusion. After full-text review against the inclusion criteria, 23 studies published between 1992 and 2018 were included in this meta-analysis [65,67,7090]. The studies reported Doppler echocardiography evidence of mitral and/or aortic regurgitation in patients with ARF in the absence of heart murmurs on cardiac auscultation. The studies were conducted in various geographical locations: Turkey $[75,78,85,88]$, India $[72,82,87,90]$, United States [73,79,86], Brazil [74,81], New Zealand [71], Qatar [70], Chile [76], Jordan [77], Cambodia/Mozambique [67], Pakistan [80], Italy [65], Austria [83], Egypt [84], and Ukraine [89]. The common criteria used for diagnosis of mitral regurgitation was mosaic color jet viewed in at least 2 planes; jet $>1 \mathrm{~cm}$; peak velocity $>2,5 \mathrm{~m} / \mathrm{s}$ and holosystolic, and aortic regurgitation was mosaic color jet viewed in at least 2 planes; jet $>1 \mathrm{~cm}$; peak velocity $>2.5 \mathrm{~m} / \mathrm{s}$ and holodiastolic. One study [67], grouped data and analysis into two sets - Cambodia and Mozambique - where each was analyzed separately.

The 23 studies enrolled 8,267 patients with suspected ARF. The patients were mostly children (mean age 10.5 years; range: $3.9-15.0$ years). There was an almost equal gender representation, with 4,016 (48.6\%) male patients. Of the 8,267 patients, 1,195 (14.4\%) did not have any clinical evidence (on auscultation) of carditis at baseline. Sixteen studies $[67,70,72-82,83,85,89]$ that reported findings of $2 \mathrm{D}$ echocardiography or Doppler echocardiography revealed evidence of subclinical carditis in 702 (58.7\%) of RF patients without clinical evidence of carditis. Further, echocardiographic evidence reveals that in RF patients without clinical evidence of carditis, the event rate of subclinical carditis (0.488), mitral regurgitation (0.351) and aortic regurgitation $(0.164)$. The findings indicate that $2 \mathrm{D}$ echocardiography and/or Doppler echocardiography offers incremental diagnostic utility in identifying subclinical carditis in patients with suspected RF without clinical evidence of carditis. 
Albakri A (2018) Rheumatic heart failure: A review of clinical status and meta-analysis of echocardiography diagnosis and efficacy of shorter duration of antibiotic

Table 7. Characteristics of studies on rhf diagnosis by clinical tests and echocardiography

\begin{tabular}{|c|c|c|c|c|c|c|c|c|}
\hline $\begin{array}{l}\text { 1st Author } \\
\text { [Ref \#] }\end{array}$ & Year & Country & $\begin{array}{l}\text { Total No. of } \\
\text { Patients }\end{array}$ & $\begin{array}{l}\text { Patients } \\
\text { without } \\
\text { Carditis }\end{array}$ & $\begin{array}{c}\text { Diagnosis Criteria for } \\
\text { Mitral }\end{array}$ & $\begin{array}{c}\text { Diagnosis Criteria for } \\
\text { Aortic }\end{array}$ & $\begin{array}{l}\text { Subclinical } \\
\text { Carditis }\end{array}$ & Summary of Findings \\
\hline Folger et al. [70] & 1992 & Qatar & 11 & 11 & $\begin{array}{l}\text { Holosystolic, peak } \\
\text { velocity }>2.5 \mathrm{~m} / \mathrm{s}\end{array}$ & $\begin{array}{c}\text { Holodiastolic, peak } \\
\text { velocity }>2.5 \mathrm{~m} / \mathrm{s}\end{array}$ & 10 & $\begin{array}{c}\text { Color flow Doppler identifies } \\
\text { subclinical (without auscultatory signs) } \\
\text { valvular disease in all stages of RF }\end{array}$ \\
\hline $\begin{array}{l}\text { Abernethy et al. } \\
{[71]}\end{array}$ & 1994 & New Zealand & 47 & 32 & $\begin{array}{c}2 \text { planes, jet } \geq 80 \% \text { of } \\
\text { systole }\end{array}$ & 2 planes, high velocity & NS & $\begin{array}{l}\text { Doppler echo is more sensitive than } \\
\text { clinical assessment in detecting } \\
\text { carditis in ARF and contribute to early } \\
\text { diagnosis }\end{array}$ \\
\hline Vasan et al. [72] & 1996 & India & 108 & 28 & $\begin{array}{l}\text { Jet }>1 \mathrm{~cm} \text { beyond } \\
\text { paravalvular region }\end{array}$ & $\begin{array}{l}\text { Jet }>1 \mathrm{~cm} \text { beyond } \\
\text { paravalvular region }\end{array}$ & 0 & $\begin{array}{l}\text { Doppler echocardiography does not } \\
\text { provide incremental diagnostic utility } \\
\text { in RF without carditis }\end{array}$ \\
\hline Minich et al. [73] & 1997 & United States & 68 & 68 & $\begin{array}{l}2 \text { planes; jet }>1 \mathrm{~cm} \\
\text { mosaic color jet; } \\
\text { holosystolic }\end{array}$ & NS & 27 & $\begin{array}{c}\text { Doppler criteria can distinguish } \\
\text { pathologic silent MR from physiologic } \\
\text { MR useful for evaluating suspected } \\
\text { ARF cases }\end{array}$ \\
\hline Da Silva [74] & 1999 & Brazil & 786 & 390 & NS & NS & 144 & $\begin{array}{c}\text { Silent carditis is prevalent in ARF } \\
\text { patients and should be considered in } \\
\text { diagnosis of ARF }\end{array}$ \\
\hline Elevli et al. [75] & 1999 & Turkey & 22 & 17 & $\begin{array}{l}2 \text { planes; jet in almost } \\
\text { entire systole }\end{array}$ & 2 planes; holodiastolic & 14 & $\begin{array}{l}\text { Color Doppler echo is useful } \\
\text { in detecting MR silent valvular } \\
\text { regurgitation }\end{array}$ \\
\hline $\begin{array}{l}\text { Figueroa et al. } \\
{[76]}\end{array}$ & 2001 & Chile & 35 & 20 & $\begin{array}{l}2 \text { planes; jet persist } \\
\text { throughout systole }\end{array}$ & NS & 16 & $\begin{array}{l}\text { Doppler echo detect subclinical valve } \\
\text { lesion, which can persist, and should } \\
\text { be a major criterion in RF diagnosis }\end{array}$ \\
\hline $\begin{array}{l}\text { Khriesat et al. } \\
{[77]}\end{array}$ & 2003 & Jordan & 50 & 26 & $\begin{array}{l}2 \text { planes; mosaic color } \\
\text { jet } \geq 1 \mathrm{~cm}\end{array}$ & NS & 4 & $\begin{array}{c}\text { Doppler echo improves clinical } \\
\text { diagnosis of RF }\end{array}$ \\
\hline $\begin{array}{l}\text { Ozkutlu et al. } \\
{[78]}\end{array}$ & 2003 & Turkey & 40 & 40 & $\begin{array}{c}2 \text { planes; mosaic color } \\
\text { jet } \geq 1 \mathrm{~cm} \text {; peak velocity } \\
>2.5 \mathrm{~m} / \mathrm{s}\end{array}$ & $\begin{array}{l}2 \text { planes; holodiastolic; } \\
\text { high velocity spectral } \\
\text { envelope }\end{array}$ & 40 & $\begin{array}{l}\text { Echo detects subclinical valvulitis as } \\
\text { evidence of diagnosis of carditis - } \\
\text { should be a major RF diagnosis }\end{array}$ \\
\hline Tani et al. [79] & 2003 & United States & 27 & 13 & $\begin{array}{l}2 \text { planes; color jet }>1 \\
\mathrm{~cm}, \text { holosystolic }\end{array}$ & $\begin{array}{c}2 \text { planes; jet }>5 \mathrm{~mm} \text { into } \\
\text { LV outflow tract }\end{array}$ & 5 & $\begin{array}{l}\text { Doppler echo provides evidence of } \\
\text { subclinical valvular disease }\end{array}$ \\
\hline \multirow{2}{*}{$\begin{array}{l}\text { Marijon et al. } \\
{[67]}\end{array}$} & \multirow{2}{*}{2007} & Cambodia & 3677 & 3 & 2 planes; holosystolic & NS & 71 & $\begin{array}{l}\text { Screening with echo compared to } \\
\text { clinical screening reveals a much } \\
\text { higher prevalence of RHF }\end{array}$ \\
\hline & & Mozambique & 2170 & NS & 2 planes; holosystolic & NS & 124 & $\begin{array}{l}\text { Screening with echo compared to } \\
\text { clinical screening reveals a much } \\
\text { higher prevalence of RHF }\end{array}$ \\
\hline Beg et al. [80] & 2008 & Pakistan & 30 & 30 & $\begin{array}{c}2 \text { planes; mosaic color } \\
\text { jet } \geq 1 \mathrm{~cm}\end{array}$ & $\begin{array}{l}\text { Holodiastolic; peak } \\
\text { velocities }>2.5 \mathrm{~m} / \mathrm{s}\end{array}$ & 13 & $\begin{array}{c}\text { Doppler echo should be performed } \\
\text { in all suspected ARF and subclinical } \\
\text { valvulitis used as a diagnostic criterion }\end{array}$ \\
\hline Caldas et al. [81] & 2008 & Brazil & 56 & 29 & \begin{tabular}{|c|} 
Mosaic color jet \\
spreading into LA during \\
systole
\end{tabular} & \begin{tabular}{|c|} 
Mosaic color jet \\
spreading into LA during \\
diastole
\end{tabular} & 25 & $\begin{array}{l}\text { Echo shows subclinical carditis in } \\
\text { patients with chorea }\end{array}$ \\
\hline $\begin{array}{l}\text { Vijayalakshmi et } \\
\text { al. [82] }\end{array}$ & 2008 & India & 333 & 165 & $\begin{array}{l}2 \text { planes; mosaic color jet } \\
>1 \mathrm{~cm}\end{array}$ & 2 planes; holodiastolic & 144 & $\begin{array}{c}\text { Precise diagnosis of carditis and } \\
\text { subclinical valvulitis is possible with } \\
\text { echo and should be included in Jones } \\
\text { criteria }\end{array}$ \\
\hline Grassi et al. [65] & 2009 & Italy & 135 & 33 & $\begin{array}{l}2 \text { planes; jet }>1 / 3 \text { of the } \\
\text { LA; holosystolic }\end{array}$ & $\begin{array}{l}2 \text { planes; jet }>1 / 3 \text { of the } \\
\text { LV holodiastolic }\end{array}$ & NS & $\begin{array}{l}\text { Echo is used to confirm carditis } \\
\text { detected by clinical assessment }\end{array}$ \\
\hline Cann et al. [83] & 2010 & Australia & 98 & 52 & NS & NS & 27 & $\begin{array}{l}\text { In ARF endemic populations } \\
\text { subclinical carditis (and ) should be } \\
\text { included in revised Jones criteria }\end{array}$ \\
\hline $\begin{array}{l}\text { Mesbah et al. } \\
{[84]}\end{array}$ & 2010 & Egypt & 34 & 14 & NS & NS & NS & $\begin{array}{l}\text { Functional echo (LVEF/LVFS) does } \\
\text { not offer relevant abnormalities due to } \\
\text { myocardial involvement }\end{array}$ \\
\hline Ekici et al. [85] & 2012 & Turkey & 69 & 39 & $\begin{array}{l}2 \text { planes; jet }>1 \mathrm{~cm} ; \\
\text { peak velocity }>2.5 \mathrm{~m} / \mathrm{s} \\
\text { persisting throughout } \\
\text { systole }\end{array}$ & $\begin{array}{l}2 \text { planes; peak velocity } \\
>2,5 \mathrm{~m} / \mathrm{s} \text {; persisting } \\
\text { throughout diastole }\end{array}$ & 20 & $\begin{array}{l}\text { Doppler echo identified subclinical } \\
\text { carditis in patients with chorea }\end{array}$ \\
\hline $\begin{array}{l}\text { Shivaram et al. } \\
{[86]}\end{array}$ & 2013 & United States & 93 & 34 & $\begin{array}{c}2 \text { planes; jet }>1 \mathrm{~cm} ; \\
\text { peak velocity }>2.5 \mathrm{~m} / \mathrm{s} \\
\text { persisting throughout } \\
\text { systole }\end{array}$ & $\begin{array}{l}2 \text { planes; peak velocity } \\
>2,5 \mathrm{~m} / \mathrm{s} \text {; persisting } \\
\text { throughout diastole }\end{array}$ & NS & $\begin{array}{l}\text { Doppler echo is more sensitive for } \\
\text { detecting valvular lesions }\end{array}$ \\
\hline Bindu et al. [87] & 2014 & India & 57 & 19 & NS & NS & NS & $\begin{array}{l}\text { Doppler echo to be performed all } \\
\text { suspected RF for early detection of } \\
\text { subclinical carditis }\end{array}$ \\
\hline
\end{tabular}




\begin{tabular}{|l|c|c|c|c|c|c|c|c|}
\hline $\begin{array}{l}\text { 1st Author } \\
\text { [Ref } \# \text { \#] }\end{array}$ & Year & Country & $\begin{array}{c}\text { Total No. of } \\
\text { Patients }\end{array}$ & $\begin{array}{c}\text { Patients } \\
\text { without } \\
\text { Carditis }\end{array}$ & $\begin{array}{c}\text { Diagnosis Criteria for } \\
\text { Mitral }\end{array}$ & $\begin{array}{c}\text { Diagnosis Criteria for } \\
\text { Aortic }\end{array}$ & $\begin{array}{l}\text { Subclinical } \\
\text { Carditis }\end{array}$ & Summary of Findings \\
\hline Basturk et al. [88] & 2016 & Turkey & 214 & 90 & 2 planes; jet $>1 \mathrm{~cm}$ & 2 planes; jet $>1 \mathrm{~cm}$ & NS & $\begin{array}{c}\text { Clinical examination and Doppler } \\
\text { echo improves diagnosis of carditis in } \\
\text { suspected ARF patients }\end{array}$ \\
\hline $\begin{array}{l}\text { Boyarchuk et al. } \\
{[89]}\end{array}$ & 2017 & Ukraine & 85 & 32 & NS & NS & 18 & $\begin{array}{c}\text { Lack of specific signs of carditis makes } \\
\text { diagnostic a challenge }\end{array}$ \\
\hline $\begin{array}{l}\text { Gautam et al. } \\
{[90]}\end{array}$ & 2018 & India & 22 & 10 & $\begin{array}{c}2 \text { planes; jet }>1 \mathrm{~cm} ; \\
\text { peak velocity }>2.5 \mathrm{~m} / \mathrm{s} ; \\
\text { jet persists throughout } \\
\text { systole }\end{array}$ & $\begin{array}{c}2 \text { planes; jet }>1 \mathrm{~cm} ; \\
\text { peak velocity }>2.5 \mathrm{~m} / \mathrm{s} ; \\
\text { jet persists throughout } \\
\text { diastole }\end{array}$ & NS & $\begin{array}{c}\text { 2d Echo Doppler in patients suspected } \\
\text { with carditis improves diagnosis of } \\
\text { subclinical carditis }\end{array}$ \\
\hline
\end{tabular}

Discussion of outcomes: In the present meta-analysis, we sought to determine whether Doppler echocardiography is able to detect subclinical carditis in RF patients. Our findings reveal that Doppler echocardiography can detect subclinical carditis in about 59\% of RF patients with negative auscultatory findings. The findings also revealed a high event rate of subclinical carditis in RF patients without clinical evidence of carditis (0.488) but the rate was not statistically significant. We also found mitral valvular incompetence is more likely in patients with subclinical carditis compared to aortic valvular incompetence. The present findings is consistent with a previous meta-analysis of 23 studies, which found the prevalence of subclinical carditis in ARF patients was $16.8 \%$, range 0 to $53 \%$ and increased to $25.5 \%$ in 10 studies applying the WHO 2012 criterion, which includes echocardiographic criteria. The prevalence of persistent or deterioration of subclinical carditis increased to $44.7 \%$ within 3 to 23 months post diagnosis [91]. The committee for Jones criteria also recognizes the value of echocardiography is well-established in distinguishing physiological from pathological valvular regurgitation [92].

Although the Jones criteria remains a hallmark in the clinical diagnosis of RHF, it is less useful in the diagnosis of early myocardial involvement leading to hemodynamic changes in patients with an acute onset of RF. Since carditis is the only manifestation of ARF that leads to permanent cardiac damage and disability, its early and accurate diagnosis is of clinical importance [78]. Echocardiography has been documented to diagnose both clinical and subclinical carditis more accurately than traditional auscultatory findings, and if integrated in the Jones criteria, may prevent both under- and over-diagnosis of valvular pathology in RF patients [82]. However, in the absence of a gold standard, it is not possible to comment on the sensitivity and specificity of diagnosis by echocardiography. The question has been asked whether echocardiography could be integrated into Jones criteria to improve diagnostic accuracy. The committee for Jones criteria is skeptical about including Doppler echocardiography as a major criteria for fear of over-diagnosis of carditis for three reasons. (a) It can detect physiological valvular regurgitation in normal individuals; (b) degree of physiological valvular regurgitation increases with age; and (c) the degree of Doppler-detected valvular regurgitation in pediatric population with febrile illnesses not related to ARF such as viral myocarditis is unknown [92]. These reasons could explain our current high event rate (0.48) of subclinical carditis in patients with no clinical evidence of carditis.

The present findings promises important clinical implications. Doppler echocardiography facility is widely available in most parts of the world and its routine use for the initial diagnosis of RHF might enhance early detection, much earlier that physical examination does [80]. In addition, the exclusion of carditis in patients with possible or acute RF cannot be confirmed without Doppler echocardiography [71]. Knowledge of the presence of subclinical carditis may also influence primary prophylaxis including the duration of treatment and bed rest, and secondary prophylaxis against recurrent ARF. Moreover, the ability to detect subclinical carditis may provide prognostic information on RHF patients. In some ARF patients, subclinical carditis may persist or deteriorate over time. Ozdemir et al. [93] report subclinical carditis persisted in $55 \%$ of the patients twelve months post diagnosis, and some RF patients without clinical evidence of carditis may develop signs of carditis when followed for 8 to 13 years [71]. These reports suggest prognostic value of echocardiography assessed subclinical carditis in RF patients and highlight the need for additional primary prophylaxis against infective endocarditis. However, additional studies are warranted to determine long-term prognostic significance of subclinical carditis.

\section{Clinical Management}

The WHO and AHA guidelines recommend primary and secondary prophylaxis for the prevention and management of RHF. The two methods have been documented to be cost-effective and inexpensive in reducing RHF burden [10,57]

\section{Preventive strategies}

Preventive strategies for RHF are categorized into primary and secondary prophylaxis designed to protect against initial and recurrent infection respectively.

\section{Primary prophylaxis}

Primary prophylaxis of RHF refers to adequate health events and measures for increasing natural immunity against an initial GAS pharyngeal infection - the primary etiologic agent for RHF. The earliest stage of primary prevention is mainly population-based, initiated to eliminate risk factors within the community [94]. These strategies include organizing general health events such as training and teaching on healthy living conditions, physical activity, sanitary and hygienic events all aimed to prevent GAS infection especially in children. Other strategies include increasing access to affordable and adequate treatment of acute respiratory diseases such as pharyngitis and tonsillitis caused by GAS. Primary prophylaxis also includes the use of pharmacological support such as antibiotic to eradicate GAS from the pharynx and to prevent RF if therapy is started within nine days after the onset of symptoms [57]. In case pharmacotherapy is not effective, tonsillectomy may be performed in the sub-acute period but not earlier than 2 months after the onset of the disease. Vaccination containing M-protein epitopes of rheumatogenic GAS not participating in crossreactions with antigen tissues from myosin may be effective for primary prevention of susceptibility of ARF in high-risk populations [67].

Secondary prophylaxis: Secondary prophylaxis of RHF is defined as continuous administration of specific antibiotics to patients with a 
prior attack of RF or well-documented RHF. The target is to prevent colonization or infection of the pharynx by GAS and the development of recurrent or chronic RF attacks. It is mandatory for individuals with prior RF attacks despite the presence or the absence of residual valvular heart disease [7,57]. The 2004 and 2009 WHO and AHA recommend the common secondary prophylaxis regimens for individuals with documented ARF should include Benzathine benzylpenicillin (intramuscular), and Penicillin V, Erythromycin, Sulfadiazine and Sulfisoxazole (delivered orally). Duration of treatment should depend on the age of the patient, the data of their last attack and the presence and severity of RHF. In highly endemic regions with increased risk of recurrence, some institutions recommend long-term or even lifelong prophylaxis for individuals with severe RHF or previous valvular surgery [94]. Secondary prophylaxis is efficiently delivered though community-based registry programs to improve compliance, education, use of healthcare worker with strong community links and integration into existing primary care. Issues affecting the efficacy include medication non-compliance, mobility of target population, understaffing of healthcare personnel and remote setting [94].

RHF surveillance: Surveillance is an essential part of preventive strategies in the management of RHF. The aim is to obtain accurate estimates of RHF burden and to allow the initiation of the most appropriate preventive therapy for as many affected or at-risk individuals as possible [57]. Disease surveillance can be achieved through passive surveys in a predefined population or retrospectively in a hospital setting. Surveys in hospital and primary care facilities allows detection of the incidence and prevalence as well as demographic data of the most affected individuals. Active screening is also important to provide data in previously unknown cases, accurate epidemiological data and guide treatment strategies including screening programs in at-risk populations [94].

\section{Meta-analysis of rhf clinical management}

Pharmacotherapy remains the cornerstone of primary and secondary prophylaxis against GAS pharyngeal infection, which is the primary etiologic agent of RF and its sequalae RHF [10,57]. The efficacy and safety of antibiotics in RF patients has been well-established. Penicillin remains the preferred antibiotic because of its proven efficacy, safety profile, narrow spectrum and low-cost. Oral penicillin administered for 10 days is recommended as standard of care because of past concerns for maximum protection against RF, which is the principal and original indication for antibiotics for pharyngitis and/or tonsillitis [10]. However, compliance for antibiotic regimens has been one of the factors affecting its therapeutic efficacy. Antibiotics cause symptoms resolution within 24 to 48 hours after treatment initiation leading to diminished motivation to complete treatment after 2 to 3 days. The 10-day penicillin treatment course therefore raises valid concern about compliance. Newer antibiotics with a shorter duration of treatment, which have been shown to be non-inferior to penicillin, would be convenient to patients and possibly improve compliance. Thus, in the present meta-analysis, we sought to summarize published evidence on clinical efficacy and safety of 3 to 6-day antibiotics and 10day penicillin treatment for the prevention of GAS infection in patients diagnosed with GAS pharyngitis and/or tonsillitis.

Search strategy and inclusion criteria: We searched for studies comparing the efficacy and safety of 2 to 6-day antibiotics with 10 day penicillin for treatment of GAS infection in PubMed/MEDLINE, EMBASE, Web of Science, and Google scholar. There was no restriction on publication time and language. Additional studies were identified through manual search of bibliographies of the included studies. The key words used in the search were: "rheumatic fever" OR "rheumatic heart" OR "streptococcal pharyngitis" OR "tonsillitis" AND "antibiotic" OR "penicillin". Studies were included if they met the following criteria. They (a) were randomized controlled trials; (b) included patients with documented acute GAS pharyngitis; (c) randomized patients into control (standard 10-day penicillin) and study arms (short 3-6 day antibiotics); (d) reported clinical outcomes - eradication of GAS, infection recurrence, treatment failure and treatment-related adverse events). Two authors independently screened all titles and abstracts, reviewed full-text for articles fulfilling inclusion criteria. Any disagreements was resolved through consensus.

Data abstraction and analysis: Studies that divided patients into more than three groups, each of the arm was analyzed as a separate study for each intervention compared against penicillin. Two reviewers independently reviewed the included studies and abstracted data on study characteristics (author, year, design, patient number and mean age), intervention details (drug and dosage), and outcome characteristics (number of patients with eradicated GAS 2 to four days after initiation of treatment, and recurrence of infection, adverse events and treatment failure after 3 to 4 weeks since initiation of therapy). Table 8 provides a summary of the main data abstracted from the included studies. We defined treatment failure as the presence of the same serotype in the follow-up tests compare to the baseline throat culture. Any discordant data was resolved by discussion and mutual agreement. We expressed categorical data as frequency, mean and standard deviation. Treatment effects of each trial were analyzed, and differences between therapeutic outcomes expressed as odds ratio (OR) and 95\% confidence interval (CI). Heterogeneity between studies was assessed using the $\mathrm{I}^{2}$ statistics and results pooled and analyzed using fixed effect model $\left(\mathrm{I}^{2}<50 \%\right)$ or random effect model $\left(\mathrm{I}^{2}>50 \%\right)$.

Study characteristics and outcomes: The online and manual bibliography search yielded 514 clinical trials for consideration. After a review of titles and abstract, 18 studies were selected for possible inclusion. A further review of full-text against the inclusion criteria excluded seven studies due to unavailability of full text of the article, did not randomize patients into study and control arms or did not include penicillin. Finally, eleven randomized controlled trials were included [95-105]. The 11 studies enrolled a combined population of 7,028 patients diagnosed with pharyngitis or tonsillitis with positive GAS throat culture. The patients were randomized into control arm standard 10-day penicillin $(4,335)$ and study arm - short duration (36) day antibiotics $(2,693)$. All the patients were children or teenagers (mean age 6.82 range $1-18$ ). The studies assessed several antibiotics with a short treatment course: azithromycin [97,104], amoxicillin $[100,102,105]$, erythromycin [99,100], cefadroxil [96], cefuroxime [101], and clarithromycin [196]. One study [95] compared clinical efficacy of 3-6 day and 10-day penicillin treatment course.

The main clinical outcomes assessed were treatment efficacy (GAS eradication, prevention of recurrence and treatment failure) and safety (treatment related adverse events). Eradiation of GAS was assessed and compared 2 to 3 days after treatment initiation while infection recurrence, treatment failure and treatment-related adverse effects were evaluated 3 to 4 weeks after treatment initiation. Pooled findings of treatment effects reveal a shorter duration of treatment (3-6 days) with once or twice daily dose has no significant difference with 10day penicillin in both efficacy and safety. Shorter and standard 10-day treatment had comparable treatment effect in eradicating GAS (OR 
Table 8. Summary of study characteristics on duration of antibiotic therapy for RHF

\begin{tabular}{|c|c|c|c|c|c|c|c|c|c|c|c|c|c|c|}
\hline \multirow[t]{2}{*}{$\begin{array}{l}\text { 1st Author } \\
\text { [Ref \#] }\end{array}$} & \multirow[t]{2}{*}{ Year } & \multirow[t]{2}{*}{ Study Design } & \multicolumn{2}{|c|}{ No, of Patients (n) } & \multirow[t]{2}{*}{$\begin{array}{c}\text { Mean Age } \\
\text { (yrs.) }\end{array}$} & \multirow[t]{2}{*}{$\begin{array}{l}\text { Antibiotic Drug and } \\
\text { Dosage Compared to } \\
\text { 10-day Penicillin }\end{array}$} & \multicolumn{2}{|c|}{$\begin{array}{l}\text { Eradication of } \\
\text { GAS }\end{array}$} & \multicolumn{2}{|c|}{$\begin{array}{l}\text { Infection } \\
\text { Recurrence }\end{array}$} & \multicolumn{2}{|c|}{$\begin{array}{l}\text { Treatment } \\
\text { Failure }\end{array}$} & \multicolumn{2}{|c|}{$\begin{array}{l}\text { Adverse } \\
\text { Events }\end{array}$} \\
\hline & & & 10-day & 3-6 day & & & 10-day & 3-6 day & 10-day & 3-6 day & 10-day & 3-6 day & 10-day & 3-6 day \\
\hline $\begin{array}{l}\text { Gerber et al. } \\
{[95]}\end{array}$ & 1987 & $\begin{array}{c}\text { Randomized } \\
\text { prospective, controlled } \\
\text { trial }\end{array}$ & 99 & 73 & $9.8(3-25)$ & $\begin{array}{c}\text { Penicillin } 250 \mathrm{mg} / \mathrm{kg} / \\
\text { dose thrice daily }\end{array}$ & NS & NS & NS & NS & 6 & 13 & NS & NS \\
\hline $\begin{array}{l}\text { Milatovic et al. } \\
\text { [96] }\end{array}$ & 1991 & Randomized trial & 105 & 104 & NS & $\begin{array}{l}\text { Cefadroxil } 25 \mathrm{mg} / \mathrm{kg} \\
\text { twice daily }\end{array}$ & NS & NS & NS & NS & 12 & 17 & NS & NS \\
\hline $\begin{array}{l}\text { Hamill et al. } \\
\text { [97] }\end{array}$ & 1993 & $\begin{array}{l}\text { Randomized } \\
\text { prospective, } \\
\text { multicenter }\end{array}$ & 47 & 49 & $7.4(2-12)$ & $\begin{array}{l}\text { Azithromycin } 10 \mathrm{mg} / \\
\mathrm{kg} \text { once daily }\end{array}$ & 42 & 39 & 3 & 5 & NS & NS & 4 & 6 \\
\hline $\begin{array}{l}\text { Adam et al. } \\
{[98]}\end{array}$ & 1995 & $\begin{array}{l}\text { Open, controlled, } \\
\text { randomized } \\
\text { multicenter study }\end{array}$ & 76 & 75 & $5.5(1-12)$ & $\begin{array}{c}\text { Cefixime } 8 \mathrm{mg} / \mathrm{kg} \\
\text { body weight/ day once } \\
\text { daily }\end{array}$ & 60 & 57 & 8 & 6 & 1 & 2 & 5 & 4 \\
\hline $\begin{array}{l}\text { Adam et al. } \\
\text { [99] }\end{array}$ & 1996 & $\begin{array}{l}\text { Randomized } \\
\text { prospective, } \\
\text { multicenter trial }\end{array}$ & 99 & 102 & $7.1(1-17)$ & $\begin{array}{c}\text { Erythromycin } 40 \mathrm{mg} / \\
\mathrm{kg} / \text { day }\end{array}$ & 87 & 85 & 6 & 11 & NS & NS & NS & NS \\
\hline $\begin{array}{l}\text { Adam et al. } \\
{[100]}\end{array}$ & 2000 & $\begin{array}{c}\text { Multicenter, } \\
\text { randomized, open- } \\
\text { labeled, controlled } \\
\text { study }\end{array}$ & 1430 & 3052 & $6.1(1-18)$ & $\begin{array}{c}\text { Amoxicillin/ } \\
\text { clavulanate/ ceftibut/ } \\
\text { cefuroxime/ } \\
\text { erythromycin estolate }\end{array}$ & 1165 & 2501 & 355 & 668 & 215 & 501 & NS & NS \\
\hline $\begin{array}{l}\text { Aujard et al. } \\
{[101]}\end{array}$ & 1995 & $\begin{array}{l}\text { Prospective } \\
\text { randomized } \\
\text { multicenter study }\end{array}$ & 103 & 97 & $6.9(2-15)$ & $\begin{array}{l}\text { Cefuroxime axetil } 20 \\
\mathrm{mg} / \mathrm{kg} / \text { day twice daily }\end{array}$ & 90 & 85 & NS & NS & NS & NS & 3 & 2 \\
\hline $\begin{array}{l}\text { Cohen et al. } \\
{[102]}\end{array}$ & 1996 & $\begin{array}{l}\text { Prospective, } \\
\text { comparative, } \\
\text { randomized, } \\
\text { multicenter trial }\end{array}$ & 160 & 161 & $5.9(3-15)$ & $\begin{array}{c}\text { Amoxicillin } 50 \mathrm{mg} / \mathrm{kg} / \\
\text { day twice daily }\end{array}$ & 116 & 118 & 3 & 5 & NS & NS & 8 & 4 \\
\hline $\begin{array}{l}\text { McCarty et al. } \\
{[103]}\end{array}$ & 2000 & $\begin{array}{l}\text { Randomized, } \\
\text { comparative } \\
\text { multicenter }\end{array}$ & 260 & 268 & $7.5(6-12)$ & $\begin{array}{l}\text { Clarithromycin } 7.5 \\
\mathrm{mg} / \mathrm{kg} \text { twice daily }\end{array}$ & 202 & 251 & NS & NS & NS & NS & NS & NS \\
\hline \multirow{2}{*}{$\begin{array}{l}\text { Cohen et al. } \\
{[104]}\end{array}$} & \multirow{2}{*}{2002} & \multirow{2}{*}{$\begin{array}{l}\text { Prospective, } \\
\text { comparative, } \\
\text { randomized, } \\
\text { multicenter trial }\end{array}$} & 169 & 167 & $6.0(2-12)$ & $\begin{array}{l}\text { Azithromycin } 10 \mathrm{mg} / \\
\mathrm{kg} / \text { day }\end{array}$ & 123 & 78 & 15 & 30 & NS & NS & NS & NS \\
\hline & & & 165 & 167 & $6.0(2-12)$ & $\begin{array}{l}\text { Azithromycin } 20 \mathrm{mg} / \\
\mathrm{kg} / \text { day twice daily }\end{array}$ & 123 & 131 & 15 & 18 & NS & NS & NS & NS \\
\hline $\begin{array}{l}\text { Lennon et al. } \\
{[105]}\end{array}$ & 2008 & $\begin{array}{c}\text { Prospective } \\
\text { randomized trial }\end{array}$ & 176 & 177 & NS & $\begin{array}{c}\text { Amoxicillin } 1500 \\
\text { mg/day }\end{array}$ & 158 & 159 & NS & NS & 11 & 10 & 4 & 9 \\
\hline
\end{tabular}

0.965; 95\% CI, 0.649-1.433; $\mathrm{p}=0.858)$; protecting against clinical recurrence (OR, 0.918; 95\% CI, 0.800-1.053; $\mathrm{p}=0.223$ ); and cases of treatment failure (OR 1.152; 95\% CI, 0.978-1.358; $\mathrm{p}=0.091)$; and treatment related adverse events (OR 1.034; 95\% CI, 0.568-1.884; $\mathrm{p}=0.912$ ) (Figures 2 to 5). The findings indicate that a short treatment course of antibiotics offer comparable efficacy (eradication of infection and protection against recurrences) and safety (fewer adverse events and cases of treatment failure to 10-day penicillin treatment.

\section{Discussion of outcomes}

The hallmark of RHF treatment is the prevention of GAS pharyngeal infection mainly through antibiotic therapy. The European Society for Clinical Microbiology and Infectious Diseases (ESCMID) [106] and the Infectious Diseases Society of America [107] guidelines on management of sore throat and infectious diseases recommend 10-day penicillin as the first line antibiotic treatment of GAS pharyngotonsillitis. The main aim is to protect against patient developing serious complications including RF and RHF. However, patient compliance with the 10-day penicillin is a concern because of rapid resolution of symptoms within 48 to 72 hours [10]. If a shorter treatment duration with newer antibiotics can have equivalent efficacy and safety with the standard 10-day penicillin treatment, it could potentially improve patient compliance. In the present, metaanalysis we compared shorter duration (3-6 days) antibiotic treatment for GAS infection with the standard 10-day penicillin treatment for efficacy and safety. We find shorter duration of treatment with once or twice daily dosage is non-inferior to the standard 10-day penicillin treatment with regard to early eradication of bacteria, protection against GAS infection, infection recurrence and treatment-associated adverse events.

Compliance with physician instructions is essential to improve the patient's health, reduce the need for additional consultation, the use of extra drugs, re-hospitalization and increased cost of care [106]. However, compliance with antibiotic therapy continues to pose important challenges to treatment efficacy. Frequency of daily dose and duration of dose strongly influences compliance. The average compliance for daily dosage decreases from once daily (70\%), twice daily (70\%), thrice daily (52\%) and four times daily (42\%) [108]. Further, treatment duration shorter than seven days also improves compliance while longer than seven days reduces compliance [109]. Similarly, in our present findings, lower daily doses (once or twice daily) for a shorter treatment duration (3 to 6 days) would improve compliance. In a previous meta-analysis, a shorter antibiotic treatment duration shows superior compliance compared to the standard 10-day penicillin therapy [110]. Although shorter treatment duration could increase the risk of relapse because of shorter time for protection against infection [108], our findings reveal comparable effect on bacteriology recurrence and treatment failure. The risk of higher daily dosage in a shorter treatment duration has been associated with increased likelihood of adverse events but we have shown incidence of adverse events are comparable to the standard 10day penicillin therapy. 
Treatment Effect on GAS Eradication

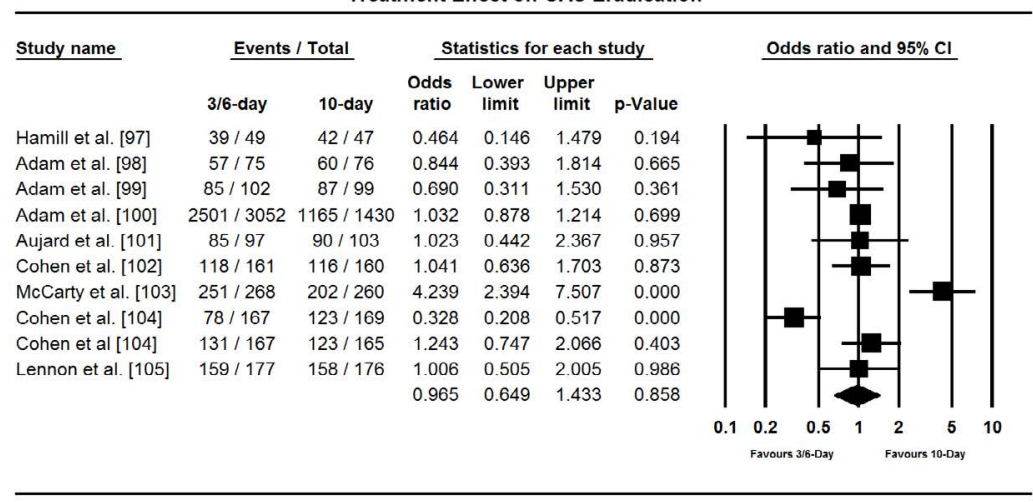

$12=82.42 \% ; p=0.00$

Figure 2. Forest plot of GAS eradication between 3-6 day and 10-day treatment

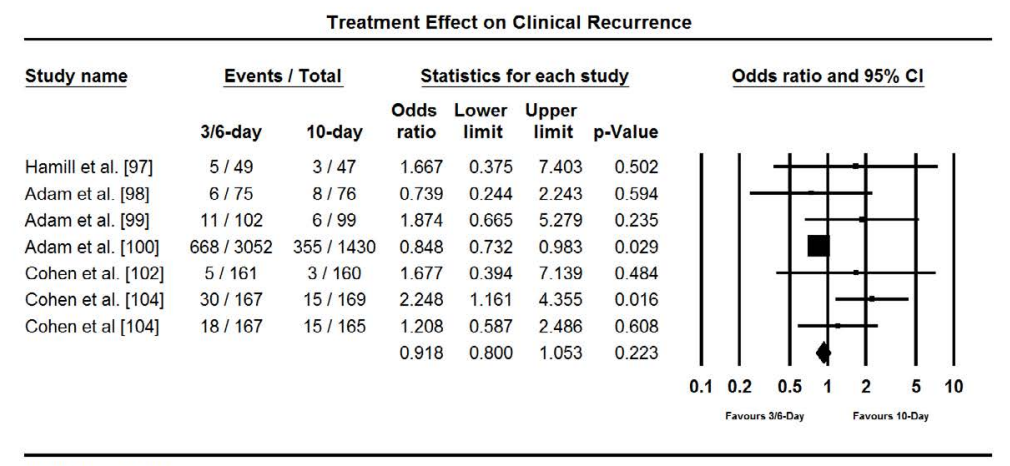

$12=49.77 \% ; p=0.063$

Figure 3. Forest plot of clinical recurrence between 3-6 day and 10-day treatment

\begin{tabular}{|c|c|c|c|c|c|c|c|c|c|c|}
\hline \multicolumn{11}{|c|}{ Cases of Treatment Failure } \\
\hline \multirow[t]{2}{*}{ Study name } & \multicolumn{2}{|c|}{ Events / Total } & \multicolumn{4}{|c|}{ Statistics for each study } & \multicolumn{3}{|c|}{ Odds ratio and $95 \% \mathrm{Cl}$} & \\
\hline & 3/6-day & 10-day & $\begin{array}{l}\text { Odds } \\
\text { ratio }\end{array}$ & $\begin{array}{c}\text { Lower } \\
\text { limit }\end{array}$ & $\begin{array}{c}\text { Upper } \\
\text { limit }\end{array}$ & p-Value & & & & \\
\hline Gerber et al. [95] & $13 / 73$ & $6 / 99$ & 3.358 & 1.211 & 9.316 & 0.020 & & & & \\
\hline Milatovic et al. [96] & $17 / 104$ & $12 / 105$ & 1.514 & 0.684 & 3.352 & 0.306 & & & & \\
\hline Adam et al. [98] & $2 / 75$ & $1 / 76$ & 2.055 & 0.182 & 23.154 & 0.560 & & & & \\
\hline Adam et al. [100] & $501 / 3052$ & $215 / 1430$ & 1.110 & 0.933 & 1.321 & 0.240 & & & & \\
\hline \multirow[t]{4}{*}{ Lennon et al. [105] } & $10 / 177$ & $11 / 176$ & 0.898 & 0.371 & 2.172 & 0.812 & & & & \\
\hline & & & 1.152 & 0.978 & 1.358 & 0.091 & & & & \\
\hline & & & & & & & 0.1 & 0.2 & 5 & 10 \\
\hline & & & & & & & & Favours 3/6-Day & Favours 10.0Day & \\
\hline
\end{tabular}

$12=25.65 \% ; p=0.250$

Figure 4. Forest plot of treatment failure between 3-6 day and 10-day treatment

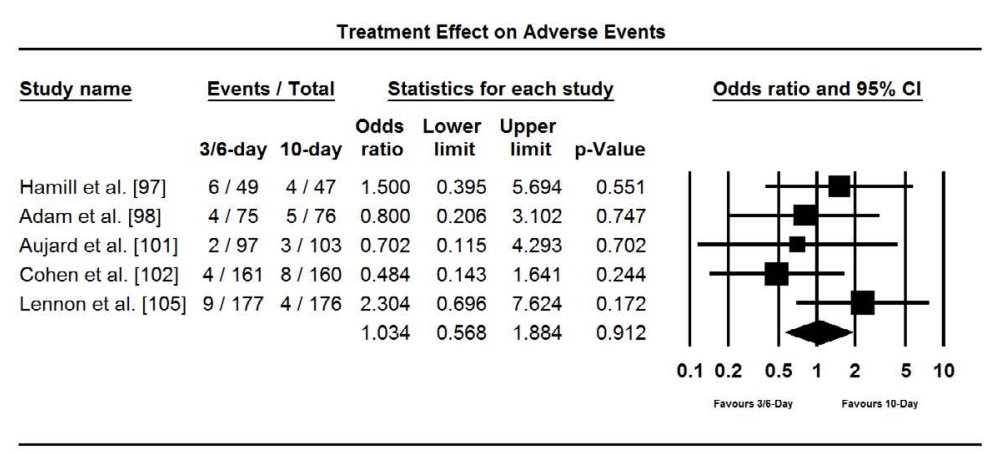

$12=0.00 p=0.431$

Figure 5. Forest plot of adverse events between 3-6-day and 10-day treatment 


\section{Conclusion}

Rheumatic heart failure (RHF) is persistent inflammation of mitral and/or aortic cardiac valves after an acute or recurrent episodes of rheumatic fever (RF) leading to valvular leakage or low cardiac output. The disease is endemic in low- and middle-income countries and in marginalized communities in high-income countries. Its major risk factors include socio-economic and environmental such as overcrowding, undernutrition and poor housing, and healthcarerelated factors such as shortage of resources, inadequate expertise, access to healthcare, and low-level of public awareness of the disease in the community. Pathogenesis results from exacerbated autoimmune response involving humoral and cellular components after group of $\mathrm{A}$ streptococcal (GAS) pharyngeal infection. Pathogenesis involves the triad of genetically susceptible host, GAS infection and exacerbated autoimmune response. Antigenic mimicry and exacerbated autoimmune response are the hallmark of RHF pathophysiology. Its major clinical features are carditis, arthritis, chorea and subcutaneous nodules while minor features include arthralgia, fever, elevated acute phase reactants and first degree heart block. Diagnosis is achieved through Jones criteria, which relies on the presence or absence of major and/or minor clinical features, and laboratory tests to identify at risk patients, and echocardiography to assess cardiac involvement. Clinical management includes primary and secondary prophylaxis to prevent exposure to GAS and initial infection, and to prevent recurrent or chronic disease mainly through the use of antibiotics and anti-inflammatory medication. Duration of antibiotics, either 10day penicillin or 3/6-day newer antibiotics, have comparable clinical efficacy and safety. Finally, disease surveillance is important to obtain accurate estimated of RHF burden and to allow initiation of appropriate prophylactic therapy for as many affected individuals as possible.

\section{References}

1. Feldman T (1996) Rheumatic heart disease. Curr Opin Cardiol 11: 126-130. [Crossref]

2. Harris C, Croce, B, Cao C (2015) Rheumatic heart disease. Ann Cardiothorac Surg 4: 492. [Crossref]

3. Carapetis JR, McDonald M, Wilson NJ (2005) Acute rheumatic fever. The Lancet 366: 155-168. [Crossref]

4. Marijon E, Ou P, Celermajer DS, Ferreira B, Mocumbi AO, Sidi D, et al. (2008) Echocardiographic screening for rheumatic heart disease. [Crossref]

5. Guilherme L, Ramasawmy R, Kalil J (2007) Rheumatic fever and rheumatic heart disease: genetics and pathogenesis. Scand J Immunol 66: 199-207. [Crossref]

6. Carapetis JR, Brown A, Wilson NJ, Edwards KN (2007) An Australian guideline for rheumatic fever and rheumatic heart disease: an abridged outline. Med J Aust 186: 581-586. [Crossref]

7. World Health Organization (2004) Rheumatic Fever and Rheumatic Heart Disease: Report of a WHO Expert Consultation, Geneva. [Crossref]

8. Lawrence JG, Carapetis JR, Griffiths K, Edwards K, Condon JR (2013) Acute rheumatic fever and rheumatic heart disease: incidence and progression in the Northern Territory of Australia 1997-2010. Circ 113. [Crossref]

9. Global Burden of Disease Collaborative Network. Global Burden of Disease Study 2016 (GBD 2016) Data Resources. Seattle, United States: Institute for Health Metrics and Evaluation (IHME [Crossref]

10. World Health Organization (2018) Rheumatic Fever and Rheumatic Heart Disease: Report by the Director-General: Seventy-First World Health Assembly A71/25, Geneva, Switzerland. [Crossref]

11. World Health Organization (2018) Health statistics and information systems: Global Health Estimates 2015. Disease burden and mortality estimates: Cause-Specific Mortality, 2000-2016. Geneva: World Health Organization; 2016. [Crossref]

12. Carapetis JR (2004) The current evidence for the burden of group A streptococcal diseases. WHO/FCH/CAH/05.07. Geneva: World Health Organization, 2004: 1-57. [Crossref]
13. Bland EF, Jones D (1951) Rheumatic fever and rheumatic heart disease: a twenty-year report on 1000 patients followed since childhood. Circ 4: 836-843. [Crossref]

14. Agarwal AK, Yunus M, Ahmad J, Khan A (1995) Rheumatic heart disease in India. $J R$ Soc Health 115: 303-339. [Crossref]

15. Htoon MT, Ngwe T, Tun N, Kyaw MM (1992) Prevalence of cardiovascular diseases in rural area of Hmawbi and urban Yangon city. Asia Pacific J Public Health 6:188-194. [Crossref]

16. Riaz BK, Selim S, Karim MN, Chowdhury KN, Chowdhury SH, et al. (2013) Risk factors of rheumatic heart disease in Bangladesh: a case-control study. $J$ Health Popul Nutr 31: 70-77. [Crossref]

17. Zaman MM, Yoshiike N, Chowdhury AH, Jalil MQ, Mahmud RS, et al. (1997) Socioeconomic deprivation associated with acute rheumatic fever. A hospital-based casecontrol study in Bangladesh. Paediatr. Perinat. Epidemiol 11: 322-332. [Crossref]

18. Okello E, Kakande B, Sebatta E, Kayima J, Kuteesa M, et al. (2012) Socioeconomic and environmental risk factors among rheumatic heart disease patients in Uganda PLoS One 7: e43917. [Crossref]

19. Dobson J, Steer AC, Colquhoun S, Kado J (2002) Environmental factors and rheumatic heart disease in Fiji. Pediatr Cardiol 33: 332-336. [Crossref]

20. Peters DH, Garg A, Bloom G, Walker DG, Brieger WR, et al. (2008) Poverty and access to health care in developing countries. Ann N Y Acad Sci 1136: 161-171. [Crossref]

21. Stock R (1983) Distance and the utilization of health facilities in rural Nigeria. Soc Sci Med 17: 563-570. [Crossref]

22. Kaplan MH, Suchy ML (1964) Immunologic relation of streptococcal and tissue antigens: II. Cross-reaction of antisera to mammalian heart tissue with a cell wall constituent of certain strains of group A streptococci. J Exp Med 119: 643-650. [Crossref]

23. Kaplan MH, Svec KH (1964) Immunologic relation of streptococcal antibody crossreactive with heart tissue: association with streptococcal infection, rheumatic fever and glomerulonephritis. J Exp Med. 19: 51-66. [Crossref]

24. Kaplan EL (1980) The group A streptococcal upper respiratory tract carrier state: an enigma J. Pediatr 97: 337-345. [Crossref]

25. Ayoub EM, Barrett DJ, Maclaren NK, Krischer JP (1986) Association of class II human histocompatibility leukocyte antigens with rheumatic fever. J Clin Invest 77: 2019 2026. [Crossref]

26. Roberts S, Kosanke S, Dunn ST, Jankelow D, Duran CM, et al. (2001) Cunningham MW. Pathogenic mechanisms in rheumatic carditis: focus on valvular endothelium. $J$. Infect. Dis 183: 507-511. [Crossref]

27. Guedez Y, Kotby A, El-Demellawy M, Galal A, Thomson G, et al. (1999) HLA class II associations with rheumatic heart disease are more evident and consistent among clinically homogeneous patients. Circ 99: 2784-2790. [Crossref]

28. Visentainer JE, Pereira FC, Dalalio MM, Tsuneto LT, Donadio, et al. (2000) Association of HLA-DR7 with rheumatic fever in the Brazilian population. J Rheumatol 27: 15181520. [Crossref]

29. Hernández-Pacheco G, Aguilar-García J, Flores-Domínguez C, Rodríguez-Pérez JM, Pérez-Hernández N, et al. (2003) MHC class II alleles in Mexican patients with rheumatic heart disease. Int J Cardiol 92: 49-54. [Crossref]

30. Khanna AK, Buskirk DR, Williams RC, Gibofsky A, Crow MK, et al. (1989) Presence of a non-HLA B cell antigen in rheumatic fever patients and their families as defined by a monoclonal antibody. J Clin Invest 83: 1710-1716. [Crossref]

31. Herdy GV, Zabriskie JB, Chapman F, Khanna A, Swedo S (1992) A rapid test for the detection of a B-cell marker (D8/17) in rheumatic fever patients. Braz J Med Biol Res 25: 789-794. [Crossref]

32. Harel L, Zeharia A, Kodman Y, Straussberg R, Zabriskie JB, et al. (2002) Presence of the d8/17 B-cell marker in children with rheumatic fever in Israel. Clin Genet 61 : 293-298. [Crossref]

33. Gibofsky A, Khanna A, Suh E, Zabriskie JB (1991) The genetics of rheumatic fever: relationship to streptococcal infection and autoimmune disease. J Rheumatol Suppl 30: 1-5. [Crossref]

34. Feldman BM, Zabriskie JB, Silverman ED, Laxer RM (1993) Diagnostic use of B cell alloantigen D8/17 in rheumatic chorea. J Pediatr 123: 84-86. [Crossref]

35. Weisz JL, McMahon WM, Moore JC, Augustine NH, Bohnsack JF, et al. (2004) D8/17 and CD19 expression on lymphocytes of patients with acute rheumatic fever and Tourette's disorder. Clin Diagn Lab Immunol 11: 330-336. [Crossref] 
36. Kumar D, Kaul P, Grover A, Ganguly NK (2001) Distribution of cells bearing B-cell alloantigen(s) in North Indian rheumatic fever/rheumatic heart disease patients. Mol Cell Biochem 218: 21-26. [Crossref]

37. Stollerman GH (2001) Rheumatic fever in the 21st century. Clin Infect Dis 33: 806814. [Crossref]

38. Wannamaker L (1973) The chain that links the heart to the throat. Circ 48: 9-18. [Crossref]

39. Kaplan EL, Anthony BF, Chapman SS, Ayoub EM, Wannamaker LW (1970) The influence of site of infection on the immune response to group A streptococci. J Clin Invest 1970; 49: 1405-1414. [Crossref]

40. Cunningham MW (2000) Pathogenesis of group A streptococcal infections. Clin Microbiol Rev 13: 470-511. [Crossref]

41. Guilherme L, Kalil J (2010) Rheumatic fever and rheumatic heart disease: cellular mechanisms leading autoimmune reactivity and disease. J Clin Immunol 30: 17-23. [Crossref]

42. Ramasawmy R, Spina GS, Fae KC, Pereira AC, Nisihara R et al (2008) Association of mannose-binding lectin gene polymorphism but not of mannose-binding serine protease 2 with chronic severe aortic regurgitation of rheumatic etiology. Clin Vaccine Immunol 15: 932-936. [Crossref]

43. Raizada V, Williams RC, Chopra P, Gopinath N, Prakash K, et al. (1983) Tissue distribution of lymphocytes in rheumatic heart valves as defined by monoclonal anti-T cell antibodies. Am J Med 74: 90-96. [Crossref]

44. Kemeny E, Grieve T, Marcus R, Sareli P, Zabriskie JB (1989) Identification of mononuclear cells and $\mathrm{T}$ cell subsets in rheumatic valvulitis. Clin Immuno Immunopathol 52: 225-237. [Crossref]

45. Guilherme L, Weidebach W, Kiss MH, Snitcowsky R, Kalil J (1991) Association of human leukocyte class II antigens with rheumatic fever or rheumatic heart disease in a Brazilian population. Circ 83: 1995-1998. [Crossref]

46. Galvin JE, Hemric ME, Ward K, Cunningham MW (2000) Cytotoxic monoclonal antibody from rheumatic carditis reacts with human endothelium: implications in rheumatic heart disease. $J$ Clin Invest 106: 217-224. [Crossref]

47. Roberts S, Kosanke S, Dunn ST, Jankelow D, Duran CM, et al. (2001) Pathogenic mechanisms in rheumatic carditis: focus on valvular endothelium. $J$ Infect Dis 183: 507-511. [Crossref]

48. Gentles TL, Colan SD, Wilson NJ, Biosa R, Neutze JM (2001) Left ventricular mechanics during and after acute rheumatic fever: contractile dysfunction is closely related to valve regurgitation. J Am Coll Cardiol 37: 201-207. [Crossref]

49. Williams RV, Minich LL, Shaddy RE, Veasy LG, Tani LY (2002) Evidence for lack of myocardial injury in children with acute rheumatic carditis. Cardiol Young 12: 519-523. [Crossref]

50. Kamblock J, Payot L, Iung B, Costes P, Gillet T, et al. (2003) Does rheumatic myocarditis really exists? Systematic study with echocardiography and cardiac troponin I blood levels. Eur Heart J 24: 855-562. [Crossref]

51. Cunningham MW (2003) Autoimmunity and molecular mimicry in the pathogenesis of post-streptococcal heart disease. Front Biosci 8: s533-543. [Crossref]

52. Dudding BA, Ayoub EM (1968) Persistence of streptococcal group A antibody in patients with rheumatic valvular heart disease. J Exp Med 128: 1081-1098. [Crossref]

53. Guilherme L, Kohler K, Kalil J (2012) Rheumatic heart disease: genes, inflammation and autoimmunity. Rheumatol Curr Res 10: 2161-1149. [Crossref]

54. Roberts S, Kosanke S, Terrence Dunn S, Jankelow D, et al. (2001) Pathogenic mechanisms in rheumatic carditis: focus on valvular endothelium. $J$ Infect Dis 183: 507-511. [Crossref]

55. Guilherme L, Kalil J (2004) Rheumatic fever: from sore throat to autoimmune heart lesions. Int Arch Allergy Immunol 134: 56-64. [Crossref]

56. Rutstein DD, Bauer W, Dorfman A, Gross RE, Lichty JA, et al. (1956) Jones Criteria (modified) for guidance in the diagnosis of rheumatic fever: report of the committee on standards and criteria for programs of care. Circ 13: 617-620. [Crossref]

57. Gewitz MH, Baltimore RS, Tani LY, Sable CA, Shulman ST, et al. (2015) Revision of the Jones Criteria for the diagnosis of acute rheumatic fever in the era of Doppler echocardiography: a scientific statement from the American Heart Association. Circ 131: 1806-1818. [Crossref]

58. Atatoa-Carr P, Lennon D, Wilson N, New Zealand Rheumatic Fever Guidelines Writing Group (2008) Rheumatic fever diagnosis, management, and secondary prevention: a New Zealand guideline. $N Z$ Med $J$ 121: 1271. [Crossref]
59. Webb RH, Grant C, Harnden A (2015) Acute rheumatic fever. Bmj 351: h3443. [Crossref]

60. Seckeler MD, Hoke (2011) The worldwide epidemiology of acute rheumatic fever and rheumatic heart disease. Clin Epidemiol 3: 67-84. [Crossref]

61. Carapetis JR, Currie BJ (1999) Rheumatic chorea in northern Australia: a clinical and epidemiological study. Arch Dis Child 80: 353-358. [Crossref]

62. Panamonta M, Chaikitpinyo A, Kaplan EL, Pantongwiriyakul A, Tassniyom S, et al (2004) The relationship of carditis to the initial attack of Sydenham's chorea. Int $J$ Cardiol 94: 241-248. [Crossref]

63. Walker AR, Tani LY, Thompson JA, Firth SD, Veasy LG, et al. (2007) Rheumatic chorea: relationship to systemic manifestations and response to corticosteroids. $J$ Pediatr 151: 679-683. [Crossref]

64. Bitar FF, Hayek P, Obeid M, Gharzeddine W, Mikati M, et al. (2000) Rheumatic fever in children: a 15-year experience in a developing country. Pediatr Cardiol 21: 119-122. [Crossref]

65. Grassi A, Fesslovà V, Carnelli V, Boati E, Dell'Era L, et al (2009) Clinical characteristics and cardiac outcome of acute rheumatic fever in Italy in the last 15 years. Clin Exp Rheumatol 27: 366-372. [Crossref]

66. Svintsitskyy AS (2015) Acute rheumatic fever: current diagnostic and therapeutic considerations. Journal Rheumatology 2015: 53-58. [Crossref]

67. Marijon E, Ou P, Celermajer DS, Ferreira B, Mocumbi AO, et al. (2007) Prevalence of rheumatic heart disease detected by echocardiographic screening. N Engl J Med 357: 470-476. [Crossref]

68. Szczygielska I, Hernik E, Kołodziejczyk B, Gazda A, Maślińska M, et al. (2018) Rheumatic fever-new diagnostic criteria. Reumatologia 56: 37-41. [Crossref]

69. Remenyi B, Wilson N, Steer A, Ferreira B, Kado J, et al. (2012) World Heart Federation criteria for echocardiographic diagnosis of rheumatic heart disease: an evidence-based guideline. Nat Rev Cardiol 9: 297-309 [Crossref]

70. Folger GM, Hajar R, Robida A, Hajar HA (1992) Occurrence of valvar heart disease in acute rheumatic fever without evident carditis: colour-flow Doppler identification Heart 67: 434-438. [Crossref]

71. Abernethy M, Bass N, Sharpe N, Grant C, Neutze J, et al. (1994) Doppler echocardiography and the early diagnosis of carditis in acute rheumatic fever Australian and New Zealand journal of medicine 24: 530-535. [Crossref]

72. Vasan RS, Shrivastava S, Vijayakumar M, Narang R, Lister BC, et al. (1996) Echocardiographic evaluation of patients with acute rheumatic fever and rheumatic carditis. Circ 94: 73-82. [Crossref]

73. Minich LL, Tani LY, Pagotto LT, Shaddy RE, Veasy LG (1997) Doppler echocardiography distinguishes between physiologic and pathologic "silent" mitral regurgitation in patients with rheumatic fever. Clin Cardiol 20: 924-926. [Crossref]

74. Da Silva CH (1999) Rheumatic fever: a multicenter study in the state of Sao Paulo. Revista do Hospital das Clínicas 54: 85-90. [Crossref]

75. Elevli M, Celebi A, Tombul T, Gökalp AS (1999) Cardiac involvement in Sydenham's chorea: clinical and Doppler echocardiographic findings. Acta Paediatrica 88: 1074 1077. [Crossref]

76. Figueroa F, Fernández MS, Valdes P, Wilson C, Lanas F, et al. (2001) Prospective comparison of clinical and echocardiographic diagnosis of rheumatic carditis: long term follow up of patients with subclinical disease. Heart 85: 407-410. [Crossref]

77. Khriesat I, Najada A, Al Hakim F, Abu Haweleh A (2003). Acute rheumatic fever in Jordanian children. East Mediterr Health J 9: 981-987. [Crossref]

78. Ozkutlu S, Hallioglu O, Ayabakan C (2003) Evaluation of subclinical valvar disease in patients with rheumatic fever. Cardiol Young 13: 495-499. [Crossref]

79. Tani LY, Veasy LG, Minich LL, Shaddy RE (2003) Rheumatic fever in children younger than 5 years: is the presentation different? Pediatrics 112: 1065-1068. [Crossref]

80. Beg A, Sadiq M (2008) Subclinical valvulitis in children with acute rheumatic fever Pediatr Cardiol 29: 619-623. [Crossref]

81. Caldas ÁM, Terreri MT, Moises VA, Silva CM, Len CA, et al. (2008) What is the true frequency of carditis in acute rheumatic fever? A prospective clinical and Doppler blind study of 56 children with up to 60 months of follow-up evaluation. Pediatr Cardiol 29: 1048-1053. [Crossref]

82. Vijayalakshmi IB, Vishnuprabhu RO, Chitra N, Rajasri R, Anuradha TV (2008) The efficacy of echocardiographic criterions for the diagnosis of carditis in acute rheumatic fever. Cardiol Young 18: 586-592. [Crossref] 
83. Cann MP, Sive AA, Norton RE, McBride WJ, Ketheesan N (2010) Clinical presentation of rheumatic fever in an endemic area. Arch Dis Child 95: 455-457. [Crossref]

84. Mesbah B, Saad A, Nasr G (2010) Myocardial involvement in the hemodynamic abnormalities associated with acute rheumatic fever. J Cardiovasc Dis Res 1: 177-180. [Crossref]

85. Ekici F, Çetin İI, Çevik BS, Senkon OG, Alpan N, et al. (2012) What is the outcome of rheumatic carditis in children with Sydenham's chorea? Turk J Pediatr 54: 159-167. [Crossref]

86. Shivaram P, Ahmed MI, Kariyanna PT, Sabbineni H, Avula UM (2013) Doppler echocardiography imaging in detecting multi-valvular lesions: a clinical evaluation in children with acute rheumatic fever. PloS one 8: e74114. [Crossref]

87. Bindu A, Jose S, Jose S (2014) Doppler echocardiography imaging as a useful tool in detecting rheumatic silent carditis. J Evol Med Dent Sci 3: 10146-10153. [Crossref]

88. Basturk A, Oztarhan K, Kavuncuoglu S, Polat C (2016) Clinical assessment and echocardiography follow-up results of the children with acute rheumatic fever. American Journal of Experimental and Clinical Research 3: 152-156. [Crossref]

89. Boyarchuk O, Boytsanyuk S, Hariyan T (2017) Acute rheumatic fever: clinical profile in children in western Ukraine. J Med Life 10: 122-126. [Crossref]

90. Gautam SK, Kushwaha JS, Verma A, Khare H, Kumar B, et al. (2018) Role of echocardiography in diagnosing subclinical cases of acute rheumatic fever and rheumatic heart disease in developing countries. J. Evolution Med. Dent. Sci. 7: 12631267. [Crossref]

91. Tubridy-Clark M, Carapetis JR (2007) Subclinical carditis in rheumatic fever: a systematic review. Int. J. Cardiol 119: 54-58. [Crossref]

92. Ferrieri P (2002) Proceedings of the Jones Criteria workshop. Circ 106: 2521-2523. [Crossref]

93. Ozdemir O, Işik S, Abaci A, Hizli S, Akelma AZ, et al. (2011) Silent enemy in acute rheumatic fever: subclinical carditis. Turk Kardiyol Dern Ars 39: 41-46.[Crossref]

94. Marijon E, Mirabel M, Celermajer DS, Jouven X (2012) Rheumatic heart disease. The Lancet 379: 953-964. [Crossref]

95. Gerber MA, Randolph MF, Chanatry J, Wright LL, De Meo K, et al. (1987) Five vs ten days of penicillin V therapy for streptococcal pharyngitis. Am J Dis Child 141: 224-227. [Crossref]

96. Milatovic D (1991) Evaluation of cefadroxil, penicillin and erythromycin in the treatment of streptococcal tonsillopharyngitis Pediatr Infect Dis $J$ 10: S61-63. [Crossref]

97. Hamill J (1993) Multicenter evaluation of azithromycin and penicillin V in the treatment of acute streptococcal pharyngitis and tonsillitis in children. J Antimicrob Chemother 31: 89-94. [Crossref]

98. Adam D, Hostalek U, Troster K (1995) 5-day cefixime therapy for bacterial pharyngitis and/or tonsillitis: comparison with 10-day penicillin V therapy. Infection 23: S83-S86. [Crossref]
99. Adam D, Scholz H, Aspe C, Berzel HG, Bulle D, et al. (1996) Five days of erythromycin estolate versus ten days of penicillin $\mathrm{V}$ in the treatment of group A streptococcal tonsillopharyngitis in children. Eur J Clin Microbiol Infect Dis 15: 712717. [Crossref]

100. Adam D, Scholz H, Helmerking M (2000) Short-course antibiotic treatment of 4782 culture-proven cases of group A streptococcal tonsillopharyngitis and incidence of poststreptococcal sequelae. J Infect Dis 182: 509-516. [Crossref]

101. Aujard Y, Boucot I, Brahimi N, Chiche D, Bingen E (1995) Comparative efficacy and safety of four-day cefuroxime axetil and ten-day penicillin treatment of group A beta-hemolytic streptococcal pharyngitis in children. Pediatr Infect Dis J 14: 295300. [Crossref]

102. Cohen R, Levy C, Doit C, De La Rocque F, Boucherat M, et al. (1996) Sixday amoxicillin vs. ten-day penicillin $\mathrm{V}$ therapy for group A streptococcal tonsillopharyngitis. Pediatr Infect Dis J 15: 678-682. [Crossref]

103. McCarty J, Hedrick JA, Gooch WM (2000) Clarithromycin suspension vs penicillin $\mathrm{V}$ suspension in children with streptococcal pharyngitis. Adv Ther 17: 14-26. [Crossref]

104. Cohen R, Reinert P, De La Rocque F, Levy C, Boucherat M, et al. (2002) Comparison of two dosages of azithromycin for three days versus penicillin $\mathrm{V}$ for ten days in acute group A streptococcal tonsillopharyngitis. Pediatr Infect Dis J 21: 297-303. [Crossref]

105. Lennon DR, Farrell E, Martin DR, Stewart JM (2008) Once-daily Amoxicillin versus Twice-daily Penicillin V in Group A $\beta$-Hemolytic Streprococcus Pharyngitis. Arch Dis Child 93: 474-478. [Crossref]

106. Pelucchi C, Grigoryan L, Galeone C, Esposito S, Huovinen P, et al. (2012) Guideline for the management of acute sore throat: ESCMID Sore Throat Guideline Group Clin Microbiol Infect 18:1-27. [Crossref]

107. Shulman ST, Bisno AL, Clegg HW, Gerber MA, Kaplan EL, et al. (2012) Clinical practice guideline for the diagnosis and management of group A streptococcal pharyngitis: 2012 update by the Infectious Diseases Society of America. Clin Infect Dis 55: e86-102. [Crossref]

108. Kardas P (2002) Patient compliance with antibiotic treatment for respiratory tract infections. J Antimicrob Chemother 49: 897-903. [Crossref]

109. Skoog G, Edlund C, Giske CG, Mölstad S, Norman C, et al. (2016) A randomized controlled study of 5 and 10 days treatment with phenoxymethylpenicillin for pharyngotonsillitis caused by streptococcus group A-a protocol study. BMC Infect Dis 16: 484. [Crossref]

110. Eide TB, Hippe VC, Brekke M. The feasibility of antibiotic dosing four times per day: a prospective observational study in primary health care. Scand J Prim Health Care $30: 16-20$. [Crossref]

111. SAltamimi S, Khalil A, Khalaiwi KA, Milner RA, Pusic MV, et al. (2009) Short versus standard duration antibiotic therapy for acute streptococcal pharyngitis in children. Cochrane Database of systematic reviews. [Crossref]

Copyright: (C2018 Albakri A. This is an open-access article distributed under the terms of the Creative Commons Attribution License, which permits unrestricted use, distribution, and reproduction in any medium, provided the original author and source are credited. 